\title{
First insights into the archaeometric analysis of the Los Amores Mosaic in Cástulo (Linares, Spain): the Judgement of Paris
}

\author{
Alberto Sánchez ${ }^{1 *} \mathbb{0}$, José Tuñón ${ }^{1}$, Manuel Montejo², Pilar Amate ${ }^{1}$, Bautista Ceprián ${ }^{1}$, Anastasia Rousaki ${ }^{3}$, \\ Mafalda Costa ${ }^{4,5}$, Delphine Saelens ${ }^{4,5}$, Sylvia Lycke ${ }^{3,4}$ and Peter Vandenabeele $e^{3,4}$
}

\begin{abstract}
This paper discusses results obtained from in situ analysis of the tesserae of the Roman mosaic of Los Amores (Cástulo site, Linares, Spain) dating back to the turn of the 1st to the 2nd century AD. Specifically, it focuses on the scene The Judgment of Paris. In view of the exceptional state of preservation of the mosaic, from which very few tesserae had fallen off, non-invasive methods with portable Micro Raman Spectroscopy (MRS) and hand-held X-ray fluorescence (hXRF) and data assessment by use of principal component analysis and binary representations were selected. The results obtained allow to evaluate both the analytical method and the portable equipment used, as well as to classify the raw materials, the colouring agents and the opacifiers used. MRS analysis proved crucial for the identification of stone tesserae (ironstones, carbonate and siliciclastic rocks) and for the identification of the type of glasses used (soda-lime-silicate and lead type glasses) based on the analysis of two detached tesserae. hXRF analysis of the glass tesserae identified both colouring agents ( $\mathrm{Co}, \mathrm{Cu}, \mathrm{Pb}, \mathrm{Zn}$ ) and opacifiers (calcium antimonate). The data obtained lend themselves to an assessment of the degradation process that threaten the integrity of the mosaic. The identification of tessera made of specific stone materials (especially ironstone) and of lead glass tesserae suggest the existence of a mosaic workshop in the Upper Guadalquivir (Eastern Andalusia, Spain).
\end{abstract}

Keywords: Roman, Mosaic, Cástulo, In situ, Portable MRS, hXRF

\section{Introduction}

The Cástulo Archaeological Zone is located on the right bank of the River Guadalimar, $5 \mathrm{~km}$ from the city of Linares (Spain) (Additional file 1: Figure S1). During its Ibero-Roman phase Cástulo would have been one of the ancient capitals of the southern Iberian Peninsula, as attested both by the size of its walled area ( $50 \mathrm{ha}$ ) and its strategic position at the head of the Guadalquivir Valley. Cástulo has a history of more than four thousand years spanning from the Chalcolithic to the fifteenth century $\mathrm{AD}$. It is a place in which diverse native cultures

\footnotetext{
*Correspondence: vizcaino@ujaen.es

${ }^{1}$ University Research Institute for Iberian Archaeology, University of Jaén, Jaén, Spain

Full list of author information is available at the end of the article
}

lived side-by-side with others from different parts of the Mediterranean.

Following the town's participation in the Second Punic War in 206 BC, it was definitively conquered by Rome under the general Publius Cornelius Scipio. From then on it was part of the Roman Empire until the crisis that began in the third century AD led to its fall. The Roman town attained considerable splendour and importance in the late first century AD. It had a theatre adorned with statues, baths, latrines, an aqueduct, a forum and an amphitheatre in which gladiator spectacles were held. Cástulo also built a water supply network that included aqueducts, pipes, tanks and fountains. This period of great splendour in Cástulo during the early Roman period contrasts with the decline it suffered in parallel with the general crisis in 
the Empire during the third century $\mathrm{AD}[1,2]$. The city rose from its ashes in the fourth and fifth centuries $A D$ [3] and was inhabited during the Islamic occupation and after the Castilian conquest at the beginning of the twelfth century AD. After several attempts to repopulate it, the town was definitively abandoned in the midfifteenth century AD [1,2].

After several decades of research inactivity, annual excavations with a notable methodological renovation [4] resumed in 2011. Thanks to this, the significance of Cástulo from an archaeological, artistic and tourism point of view has been reactivated. This aspect is very important as the archaeological site is one of the main tourism and economic assets of the town of Linares, which has been immersed for many years in a profound economic depression.

There can be no doubt that one of the most spectacular outcomes of this new activity was the excavation of the so-called Building D, a Roman-period building of approximately $33 \times 12 \mathrm{~m}$ dated to the late first century AD [5, 6]. It was built in honour of Emperor Domitian (51-96 $\mathrm{AD})$ and would have been a public building. Its construction would have been part of an imperial project, a representation of the maiestas imperii, and also of the emperor himself as a representative of them. The excavations begun in 2011 have so far identified ten rooms in Building D (Additional file 1: Figure S1), several of them decorated with mosaics and mural paintings [7]. The most outstanding is Room 1 with its splendid decoration known as the Los Amores Mosaic (Additional file 1: Figures S2) [6, 8]. The 11.65-m-long, 5.75-m-wide mosaic is almost completely preserved. Its composition is a variation on the so-called compass or a oculi scheme, incorporating two central circles instead of the more normal one [6]. The origin of the compass scheme can be found in Italy, in black and white designs in Pompeii, Ostia and Lucera. From Italy it would have been disseminated to the provincial workshops in the rest of the empire, including Hispania, in the late first century AD [9].

The right-hand circle contains a depiction of the Judgement of Paris (Fig. 1) and that on the left the myth of Selene and Endymion. The half circles on the longest sides are decorated with four Erotes in profile offering bunches of grapes to a partridge and a pheasant. The other two half circles on the shorter sides are also illustrated with Erotes, although in this case they are hunting a hare. The quarter circles in the corners contain allegoric busts of the seasons with their characteristic attributes. They represent the passage of time and annual fertility, a theme that was not just philosophical but also linked to wellbeing. This was a very common subject in Roman mosaics and was particularly prevalent in the Baetica region.
The six oblong quadrangular spaces are occupied by mammalian, herbivorous and carnivorous animals in an attitude of running through a rocky landscape: on one side a wild boar, a lion and a horse, and on the other, a tigress, a deer and a lioness.

In general, the Cástulo mosaic has a dual significance. On the one hand it has been suggested that the figurative scenes have a moralising content linked to the excesses of love and the imbibing of wine [6]. On the other, it would have formed part of an architectural and iconographic discourse related to the legitimation of power and the consolidation of the legitimate, continuous and eternal nature of Roman and imperial domination. In this respect, the presence of the Judgement of Paris connects the origin of Rome to the history of Troy, as, according to one Roman legend, the foundation of the former was linked to Trojan hero Aeneas $[10,11]$. This second interpretation would be in keeping with the building in which it was found. All the evidence points to this having had a public, propagandistic and legitimating function: its size and internal structure, the quality of the materials used, the presence of quality mosaics and mural decorations, the absence of productive and/or domestic activities, the location near the urban centre, and its unique nature in the town of Cástulo [5].

\section{Aims}

In 2018, an archaeometric analysis of the Los Amores Mosaic was undertaken as part of the "Cástulo: Archaeometric Analysis and Social Transfer" Research Project. From all the scenes, the Judgement of Paris was chosen as the most representative for demonstrating the initial results of the project and to evaluate the mosaic's main characteristics. Thus, the objectives proposed with this study are two-fold.

Firstly, given the artistic, archaeological and historical importance of the Los Amores Mosaic and the scene of the Judgement of Paris, the first objective proposed was the archaeometric analysis of the tesserae. This research can be added to the stylistic, iconographic and historical research already undertaken $[5,6,12,13]$, thus completing the comprehensive study of the mosaic. In this respect, the mineral and elemental analysis should conclude with the spectroscopic characterisation of the tesserae to identify the raw materials (stone, glass, ceramic), colouring agents and opacifiers. This study should also provide fundamental information for evaluating the state of the mosaic's conservation and the possible maintenance and restoration measures.

Depictions of the Judgement of Paris are documented in only two mosaics in Hispania: one in the villa of El Alcaparral, Casariche (Seville) [14] and the other in the villa of Noheda (Cuenca), both from the fourth century 


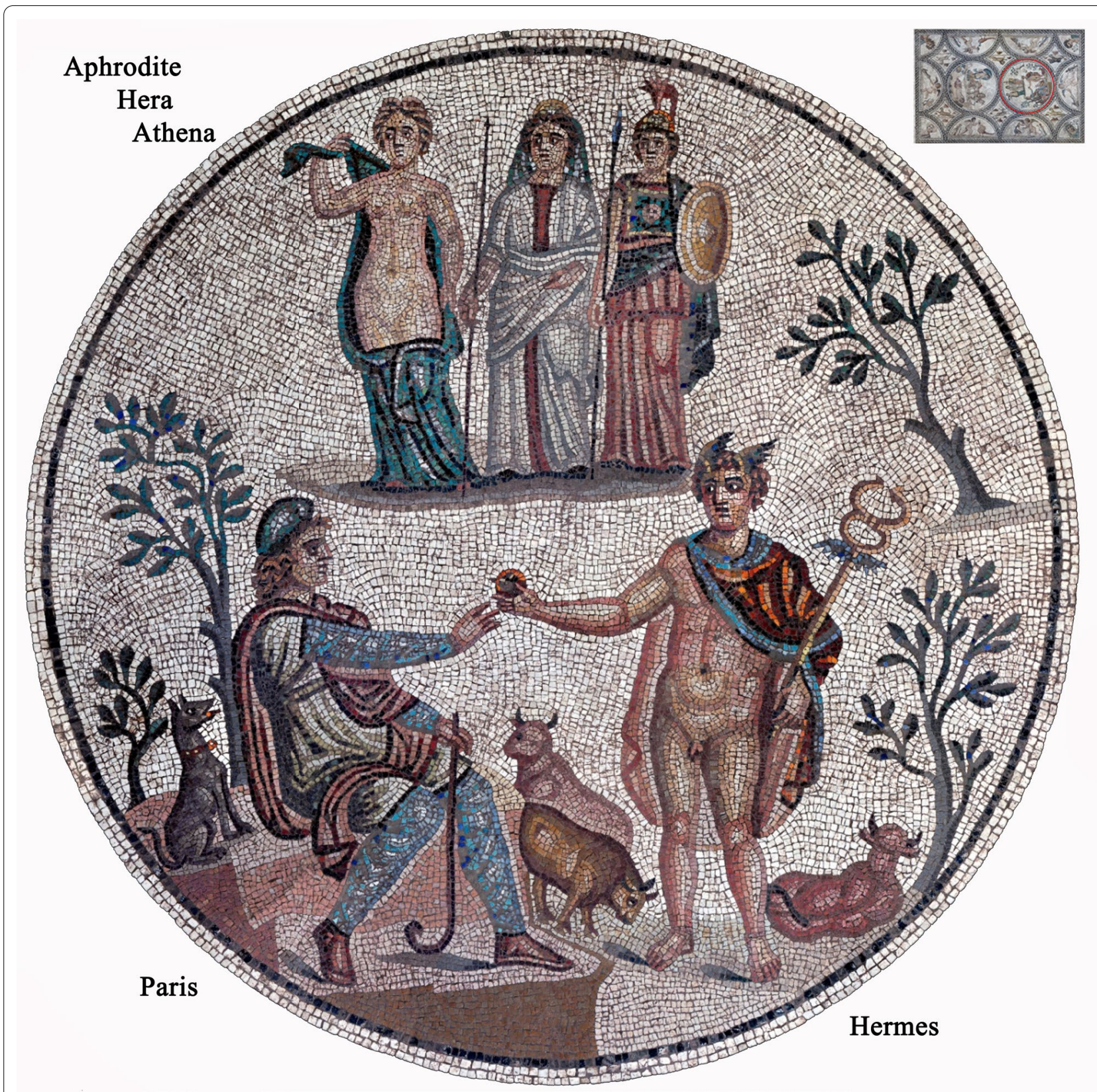

Fig. 1 The Judgement of Paris. Los Amores mosaic in Cástulo (Linares, Spain)

AD [15]. The scene also appears in the mosaics of the Atrium House in Antioch on the Orontes (Turkey) from the first half of the second century AD; in the baths on the island of Kos (Greece) from the late second and early third centuries AD [16]; in the colony of Ulpia Traiana Augusta Dacica Sarmizegetusa (Romania) from the second-third centuries AD; and in Caesarea (Algeria) from the fourth century AD. Of all of them, only the Noheda mosaic has been subjected to an archaeometric analysis, although that focused solely on the glass tesserae $[17,18]$.
The methodological dimension of the second objective was aimed at exploring the capacity and enhancing the use of portable equipment in the in-situ analysis of mosaics. Given the undesirability of disturbing them by removing a significant repertory of the tesserae for study, non-invasive strategies need to be developed to analyse them in situ. Thus, this proposal comprises the use of portable equipment able to carry out readings of the mineral (portable MRS) and elemental (handheld XRF) compositions. A joint analysis undertaken with both 
techniques allows us to analyse both stone and glass tesserae with greater guarantees.

The spectroscopic techniques selected have been used frequently and successfully on Roman mosaic tesserae from all over the Mediterranean, although in those cases by analysing separate tesserae with high precision laboratory equipment [19-23]. In contrast, the combined application of portable equipment to analyse mosaics has so far been infrequent [24-26]. Nevertheless, it is necessary because in many cases it is the only option for undertaking a comprehensive study of a mosaic. Los Amores Mosaic is an excellent example of this situation. Our investigation also had the advantage of preliminary studies in which the effectiveness of various types of portable Raman and hXRF equipment were tested, with the specific portable devices used showing good applicability and performance $[27,28]$.

\section{Experimental Sampling}

Prior to the identification of the colours and the analysis, the tesserae were treated by removing all the dust with a soft bristle brush and cleaning the surface with a solution of water and methanol. Following this operation, the tesserae were identified on the mosaic and selected according to their colour. A high-resolution gigapixel image available in GigaPan was also used as a complementary tool [29].
We analysed 92 tesserae from The Judgment of Paris scene using portable MRS and hXRF instruments (Additional file 1: Figures S3-S7). The tesserae were chosen to account for all the colours and chromatic variations (Fig. 2) in the scene. This large number allowed us to minimise identification and measurement errors caused by the difficulty of accurately directing the laser and/or $\mathrm{X}$-ray beam over the mosaic surface.

In addition to these 92 samples, two loose vitreous tesserae found during the archaeological excavation of the Paris mosaic were further analysed using MRS laboratory equipment, with the aim of completing the analytical characterisation (Fig. 3).

\section{Micro Raman spectroscopy}

All the equipment and the experimental parameters are as described in Rousaki et al. [27], Tuñón et al. [30] and Sánchez et al. [31].

The portable equipment used was a BWS445-785S innoRam $^{\text {TM }}$ Raman spectrometer (B\&WTEK, Inc., Newark, USA) with a $785 \mathrm{~nm}$ excitation laser (maximum power of $300 \mathrm{~mW}$ ) and a $\sim 4 \mathrm{~cm}^{-1}$ spectral resolution. The spectrometer was attached to a TE-cooled, back-thinned, 2D binning CCD detector. For measuring the tesserae from the Los Amores Mosaic, a 1.5-m fibre optic probe was focused by hand. The lens used had a $5.9-\mathrm{mm}$ working distance regulator that ensured proper focusing while minimising contamination and
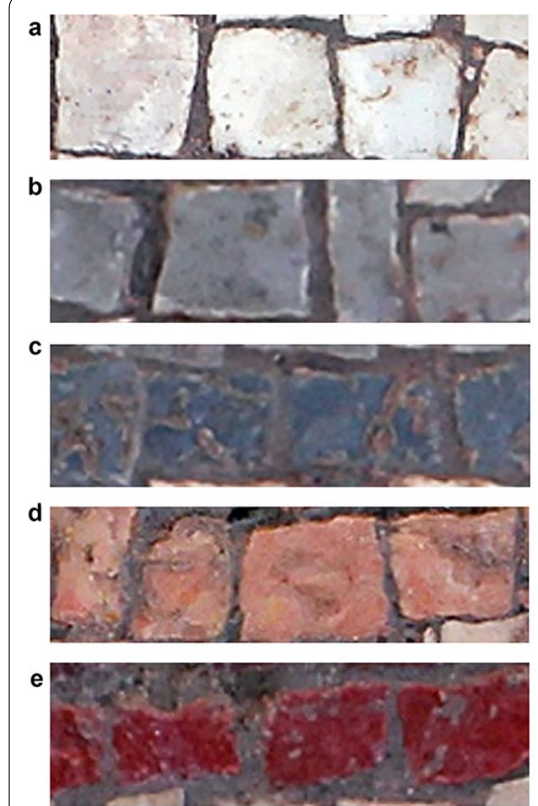
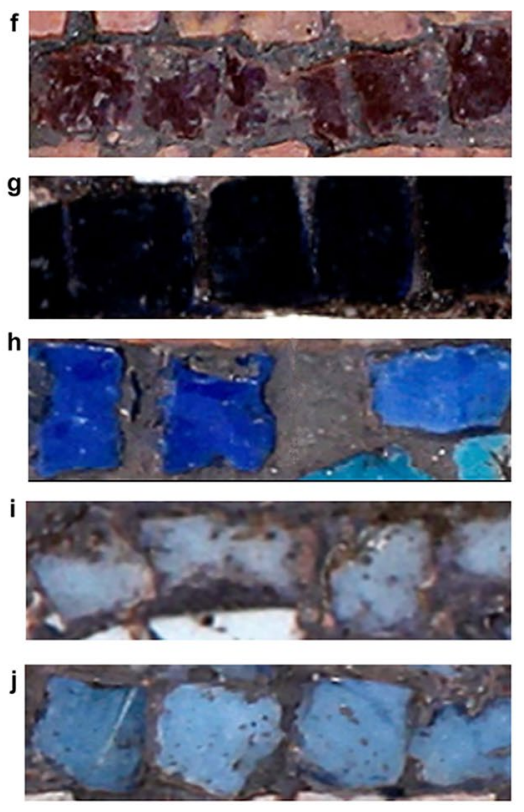
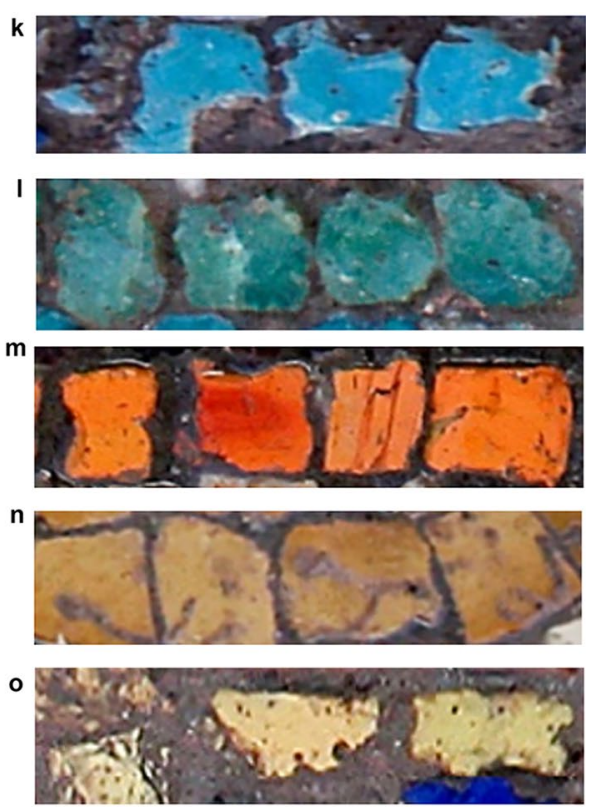

Fig. 2 Colours analysed in the Judgement of Paris and Munsell classification. a White 2.5Y 8/0. b, c Greys N 6/0, N 5/0. d Pinkish-beige 2.5YR 7/4. e f Reds 7.5R 4/8, 7.5R 3/3-3/4. g Black N 1.7/0. h, i Blues 5 PB 5/10, 5 PB 8/2. j-I Turquoise-green 5 PB 8/4, 7.5B 7/8, 5BG 6/4. $\mathbf{m}$ Orange 5YR 7/8. n, o Yellows 10YR 6/6-7/6, 5Y 9/8 
a

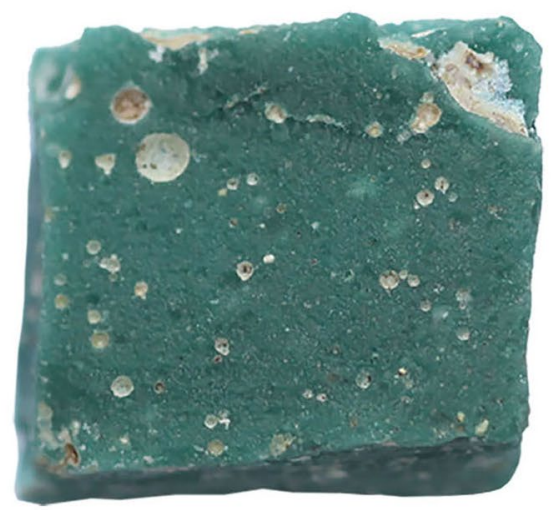

b

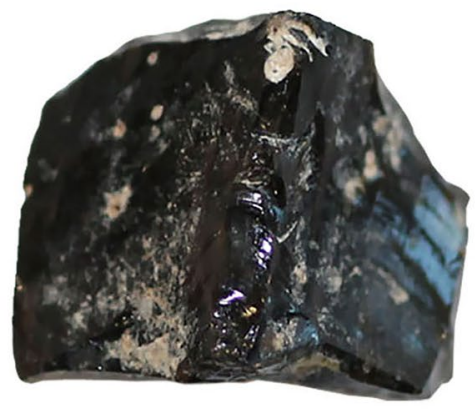

\section{$1 \mathrm{~cm}$}

Fig. 3 Loose tesserae from The Judgement of Paris. a Green tessera. b Black tessera

degradation of the lens material. The spot size was $85 \mu \mathrm{m}$. The laser power was kept low and the measurement time and accumulations were adapted in order to acquire acceptable signal-to-noise $(\mathrm{S} / \mathrm{N})$ ratio. No special calibration was applied. Before each measurement, a dark scan was executed to improve the $\mathrm{S} / \mathrm{N}$ ratio in the Raman spectra. The experimental conditions were exposure time ranging from 100 to $1000 \mathrm{~ms}$, maximum power of $40 \%$, maximum 60 acquisitions and a spectral range of between 65 and $3000 \mathrm{~cm}^{-1}$. This equipment was powered both by a Pb-ion battery (MICROBEAM S.A., Barcelona, Spain) and a portable generator. Raman spectra were recorded using the BWSpecTM 3.26 software version (B\&W Tek Inc.).

For the analysis of the loose tesserae, the laboratory equipment used was a Renishaw inVia Qontor Spectrometer (University of Málaga, SCAI-UMA) coupled with a Leica confocal microscope equipped with three lasers: solid state $(473 \mathrm{~nm}, 8 \mathrm{~mW}$ on sample), Nd:YAG (532 nm, $27 \mathrm{~mW}$ on sample) and diode (785 nm, $140 \mathrm{~mW}$ on sample). The spectrometer was attached to a Peltier-cooled CCD detector. This device consisted of two gratings of $2400 \mathrm{l} / \mathrm{mm}$ for the $473-\mathrm{nm}$ and $532-\mathrm{nm}$ lasers and $1200 \mathrm{l} / \mathrm{mm}$ for the $785-\mathrm{nm}$ laser. The spot size was $\sim 1 \mu \mathrm{m}$. The spectra were acquired using the $50 \times$ objective lens in the $100-3000 \mathrm{~cm}^{-1}$ region with a spectral resolution of $\sim 1 \mathrm{~cm}^{-1}$. Acquisition time was set at between 1 and $20 \mathrm{~s}$ per accumulation and the maximum number of accumulations was 20 .
The interpretation of the spectra was carried out by comparison with related literature, freely available RRUFF and Raman databases [32-35].

\section{X-Ray Fluorescence (hXRF)}

The equipment and the experimental parameters are as described in Costa et al. [28]. The in-situ analyses were performed with an Olympus Innov X Delta Premium commercial instrument coupled with a rhodium $(\mathrm{Rh})$ anode-based X-ray tube and a $20-\mathrm{mm}^{2}$ silicon drift detector (SDD). An aluminium (Al) filter was applied for measuring the higher $\mathrm{Z}$-elements (from $\mathrm{Al}$ onwards) with a voltage of $40 \mathrm{kV}$ and a current of $38.7 \mu \mathrm{A}$. Without filtering (low- $\mathrm{Z}$ elements), a voltage of $10 \mathrm{kV}$ and a current of $50.8 \mu \mathrm{A}$ can be applied. The measurements were performed in air for $150 \mathrm{~s}$ (live time) with the Geochem mode of the instrument. All measurements were performed with a collimated polychromatic X-ray beam for excitation $\left(3 \times 3 \mathrm{~mm}^{2}\right)$. This equipment also had a camera that allowed the correct positioning of the instrument and viewing of the analysed area. The calibration of the spectrometer was automatic using an alloy 316 stainless steel. Each sample was analysed in one location. The portable equipment was powered by removable Li-ion batteries. The collected spectral data were processed using the dedicated XRF spectrum evaluation software AXIL (Analysis of X-ray Spectra by Iterative Least Squares) [36, 37]. The hXRF values shown in this 
work mean the raw net peak intensity of $K \alpha$ and $L \alpha$ lines of detected elements in XRF spectra.

\section{Data analysis}

To obtain an objective classification of the tesserae, a principal component analysis (PCA) was carried out using the hXRF data. All the PCA analyses were run on the correlation matrix of the raw net counts of $K \alpha$ and $L \alpha$ lines of the detected elements using the statistical tools from OriginPro v.2019 (OriginLab Corp). Previously to statistical analysis, the elements values were scaled and normalised. Scores were standardised by default with a correlation matrix using OriginPro. Those elements that were detected only in a few tesserae have not been included in the PCA.

The first analysis of all 82 tesserae was performed on the data from 14 elements $(\mathrm{Mg}, \mathrm{Al}, \mathrm{Si}, \mathrm{P}, \mathrm{Cl}, \mathrm{K}, \mathrm{Ca}, \mathrm{Ti}$, $\mathrm{Mn}, \mathrm{Fe}, \mathrm{Cu}, \mathrm{Zn}, \mathrm{Sr}, \mathrm{Pb})$. Principal components PC 1 and PC 2, with eigenvalues of 5.18 (percentage of variance: $37.02 \%$ ) and 2.61 (percentage of variance: $18.66 \%$ ), account for an explained variance of $55.67 \%$ and were represented on scores and loading plots graphs. Based on the results of this PCA another two were carried.

The second PCA was performed on the 35 stone tesserae using data from the 15 most common elements in the characterisation of this type of tessera [26] (Mg, $\mathrm{Al}, \mathrm{Si}, \mathrm{P}, \mathrm{S}, \mathrm{Cl}, \mathrm{K}, \mathrm{Ca}, \mathrm{Ti}, \mathrm{Mn}, \mathrm{Fe}, \mathrm{Cu}, \mathrm{Zn}, \mathrm{Sr}, \mathrm{Pb})$. Principal components PC 1 and PC 2, with eigenvalues of 9.49 (percentage of variance: 63.27\%) and 1.54 (percentage of variance: $10.29 \%$ ), account for an explained variance of $73.56 \%$ and were represented on scores and loading plots graphs.

The third PCA was applied to the 47 glass tesserae based on the data from 9 characteristic elements of the most common chromophore and opacifier groups [18] ( $\mathrm{Si}, \mathrm{Ca}, \mathrm{Mn}, \mathrm{Fe}, \mathrm{Ni}, \mathrm{Cu}, \mathrm{Zn}, \mathrm{Sb}, \mathrm{Pb}$ ). In some cases it has been described how high lead values can interfere with the measurement of certain elements [38-41]. This effect was only clearly corroborated in the $\mathrm{Rb}$, which was therefore eliminated as a variable of the PCA. Principal components PC 1 and PC 2, with eigenvalues of 4.52 (percentage of variance: $50.26 \%$ ) and 1.71 (percentage of variance: $19.02 \%$ ), account for an explained variance of $69.27 \%$ and were represented on scores and loading plots graphs.

Based on the PCA and for the detailed analysis of small groups of tesserae of the same typology or colour, an analysis of the characteristic chemical elements was undertaken through binary representations and/or based on characteristic indices of pairs of chemical elements with ability for discrimination.

\section{Results}

\section{Types of tesserae}

As shown in Fig. 4, PCA offers an impartial criterion based on hXRF data to classify the tesserae into three main groups: two made up of stone and one of glass.

The first group was made up of 28 white, black, grey, red, pinkish-beige (also known as nudes) and mustardyellow stone tesserae characterised by high $\mathrm{Ca}, \mathrm{Mg}, \mathrm{Fe}$ contents. The second group included 7 black tesserae with significantly higher levels of $\mathrm{Al}, \mathrm{K}$ and $\mathrm{Ti}$ than the rest.

The colours of the group of 47 vitreous tesserae were black, red, blue, green, turquoise, yellow and orange with high levels of $\mathrm{Si}, \mathrm{Co}, \mathrm{Cu} \mathrm{Sn}, \mathrm{Sb}$ and $\mathrm{Pb}$. In contrast to other Roman mosaics [42-44], no ceramic tesserae were identified in the Judgement of Paris mosaic.

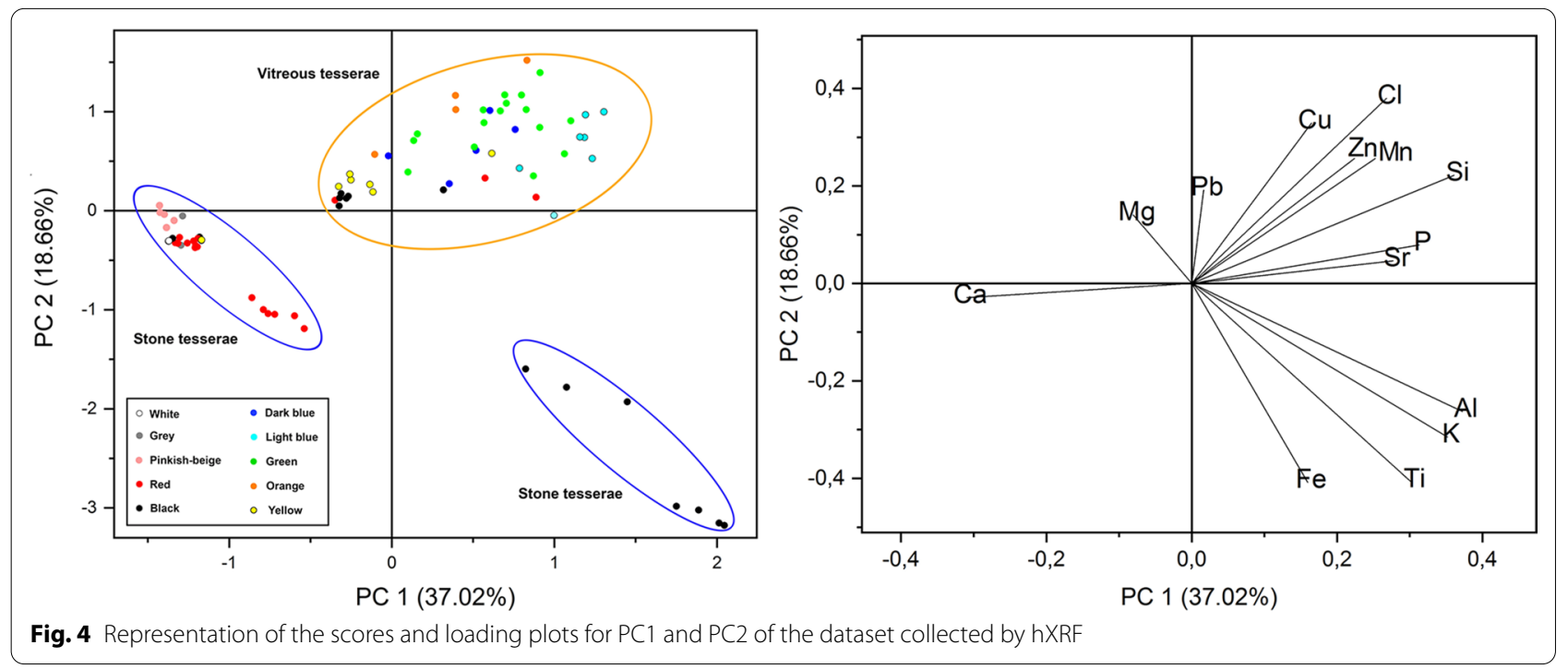




\section{Types of glass matrix}

In the case of the glass tesserae, not only is the nature of the chromophore interesting but also the type of glass. In this respect, considering the limitations of in-situ MRS and hXRF analyses, we carried out a thorough analysis using MRS laboratory equipment of two individual tesserae (one green and one black) that were found detached from but close to the Judgement of Paris mosaic.

The Raman spectrum of an amorphous silicate is composed of two broad bands at around 500 and $1000 \mathrm{~cm}^{-1}$ that are assigned to the symmetric bending of the $\mathrm{SiO}_{4}$ tetrahedra $\left(\delta_{\mathrm{s}} \mathrm{SiO}_{4}\right)$ and the symmetric stretching of the $\mathrm{Si}-\mathrm{O}$ bonds $\left(v_{\mathrm{s}} \mathrm{SiO}_{4}\right)$, respectively [45]. Observed bands are indicative of certain additives, the presence of which allows the classification of the glass. Thus, the Raman spectrum of the green tessera presents a clear profile associated with soda-lime-silicate glass corresponding to "Glass Family 3" in the Raman signature guide [34, 45, 46]. In the Raman spectrum we can also clearly identify the main bands at 235, 324, 335, $669 \mathrm{~cm}^{-1}$ (Fig. 5a). All these peaks are characteristic of the calcium antimonate $\left(\mathrm{Ca}_{2} \mathrm{Sb}_{2} \mathrm{O}_{7}\right)$ orthorhombic phase that acts as an opacifier agent $[45,47]$.

In the case of the black tessera, the Raman spectrum profile fits the model or pattern described for lead glass classified in "Glass Family 7" (Table 1) [34, 46]. In general, a lead-rich glass is easily identified by a strong stretching mode at $959 \mathrm{~cm}^{-1}$ (Fig. 5b). In the case of this tessera, the variation in the value of the stretching mode is linked to the concentration of $\mathrm{Pb}$. An increase in the amount of lead causes a red-shifting of this vibrational mode [34, 47].

From the data obtained from both types of tesserae we can see that at least two types of glass are present in the group of 47 vitreous tesserae analysed. Judging from the
$\mathrm{Pb}$ values obtained in the hXRF analysis, only one group of 6 black tesserae shows extremely high $\mathrm{Pb}$ values that would place them in the lead glass category. The rest of glass tesserae could be classified as alkali-silicate glass type.

\section{Colours and raw materials}

The applied methodology, based on the joint analysis by MRS, hXRF and on the statistical treatment from PCA and analysis of two variables, has allowed the identification and classification of the types of rock, chromophores and opacifiers used in the manufacture of the tesserae.

The PCA of the stone tesserae succeeded in differentiating a group of red tesserae with high Fe values $(18,19$, $20,2345,59,60,87,88$ ) and two groups of black tesserae, while the white, grey, red, black and yellow tesserae remained grouped with little definition (Fig. 6). In those cases, the MRS mineralogical analysis and the analysis of two variables provided fundamental information for improving their classification.

The PCA of the glass tesserae identified the orange, light blue, black and intense green groups of tesserae, while the dark blue and red tesserae and the others whose colour and opacity depends on their lead content (dark and light turquoise and yellow) were less well defined (Fig. 7) [40, 41]. In those cases, once again the analysis of two variables was necessary to improve their characterisation.

\section{White}

The Raman spectra of the white tesserae $(5,41,75)$ present the typical bands of calcite at 155, 282, 712 and $1086 \mathrm{~cm}^{-1}[48,49]$, meaning they were made mainly of limestone (Fig. 8a) (Table 1). The Ca values registered in the hXRF analysis make them the tesserae with the highest $\mathrm{Ca}$ content in the whole scene and confirm their
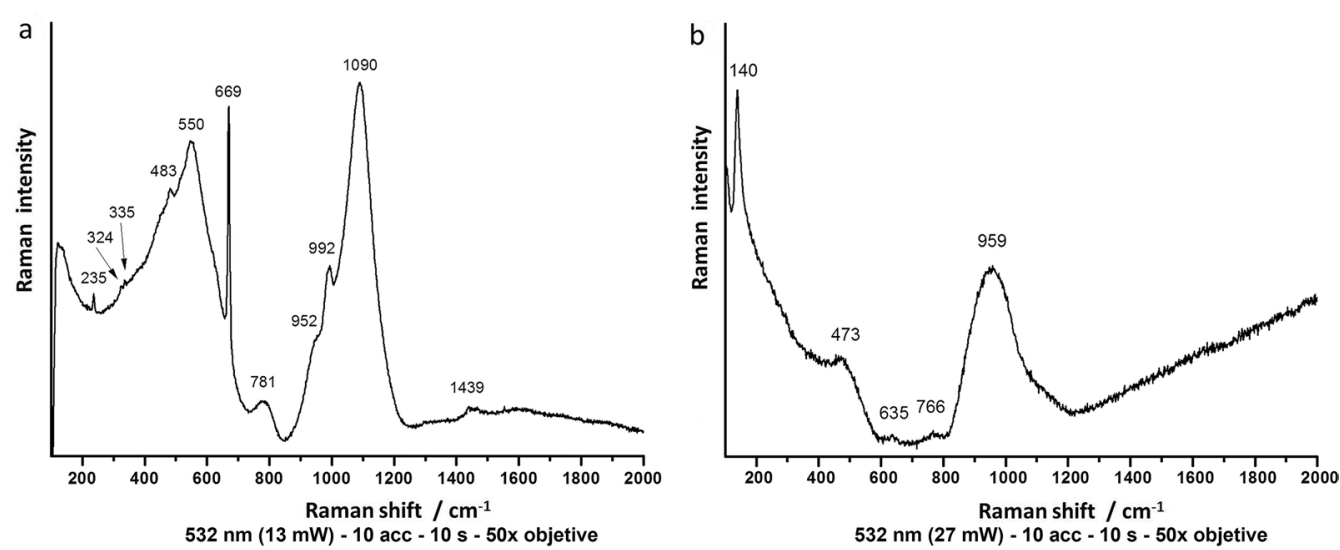

Fig. 5 Raman spectra. a Green tessera, soda-lime-silicate glass. b Black tessera, lead glass 
Table 1 Raman spectroscopy results

\begin{tabular}{|c|c|c|c|}
\hline Colour & Tesserae & Raman bands $\left(\mathrm{cm}^{-1}\right)$ & Compound \\
\hline \multirow[t]{3}{*}{ White } & 5 & 280,1086 & Calcite $[48,49]$ \\
\hline & 41 & $282,711,1086$ & \\
\hline & 75 & $155,282,712,1086$ & \\
\hline \multirow[t]{5}{*}{ Beige } & 14 & $175,300,725,1097$ & Dolomite $[35,48]$ \\
\hline & 52 & $175,299,724,1098$ & \\
\hline & 56 & $174,300,1097$ & \\
\hline & 71 & $175,299,1097$ & \\
\hline & 72 & $175,300,1098$ & \\
\hline \multirow[t]{14}{*}{ Red } & 18 & $224,291,410,609$ & Hematite $[35,50]$ \\
\hline & 19 & $224,291,409,610$ & \\
\hline & 20 & $224,242,291,410,611$ & \\
\hline & 23 & $224,292,410$ & \\
\hline & 45 & $223,291,410,613$ & \\
\hline & 59 & $224,291,409,610$ & \\
\hline & 60 & $224,290,410$ & \\
\hline & 87 & $224,290,409$ & \\
\hline & 88 & $224,292,410$ & \\
\hline & 90 & $154,282,711,1086$ & Calcite $[48,49]$ \\
\hline & 40 & 282,1084 & \\
\hline & 54 & 281,1086 & \\
\hline & 63 & $154,177,282,299,712,1086,1098$ & Calcite $[48,49]$, dolomite $[35,48]$ \\
\hline & 76 & $156,282,710,1086$ & Calcite $[48,49]$ \\
\hline \multirow[t]{6}{*}{ Black } & 34 & 281,1086 & Calcite $[48,49]$ \\
\hline & 42 & 282,1086 & Calcite $[48,49]$ \\
\hline & 43 & $142,397,463,515,636$ & Anatase $[32,33]$, quartz $[33,35]$ \\
\hline & 78 & 142 & Anatase $[32,33]$ \\
\hline & 79 & 141 & Anatase $[32,33]$ \\
\hline & BT & $140,473,635,766,959$ & Lead glass Raman signature $[34,46,47]$ \\
\hline \multirow[t]{7}{*}{ Blue } & 9 & 670 & Calcium antimonite $[24,45]$ \\
\hline & 10 & 670 & \\
\hline & 11 & 670 & \\
\hline & 12 & 670 & \\
\hline & 47 & 670 & \\
\hline & 68 & 670 & \\
\hline & 91 & 670 & \\
\hline Green & GT & $235,324,335,483,550,669,781,952,992,1090$ & $\begin{array}{l}\text { Soda-lime-silicate glass Raman signa- } \\
\text { ture }[34,45,46] \\
\text { Calcium antimonate }[24,45]\end{array}$ \\
\hline
\end{tabular}

$B T$ loose black tessera, GT loose green tessera

classification among the calcareous rocks known as limestones (Table 1).

\section{Grey}

Two types of grey tesserae were analysed (Fig. 2b, c): clear (33) and dark (44). Neither case provided a well-defined Raman spectrum, although their high $\mathrm{Ca}$ values indicate that both were made of limestone (Table 2). The somewhat more notable presence of $\mathrm{Mg}$ in Tessera 33 could nuance the result for the type of rock used and bring it closer to the dolomitic limestone category (Table 4).

\section{Pinkish-beige}

The set of analysed tesserae (14, 52, 56, 71, and 72) repeatedly shows the characteristic Raman bands of dolomite rock at 175, 300, 725, $1097 \mathrm{~cm}^{-1}$ [47] (Table 1) (Fig. 8b). The elemental analysis by hXRF, characterised by high relative amounts of $\mathrm{Mg}$ and, to a lesser extent, 

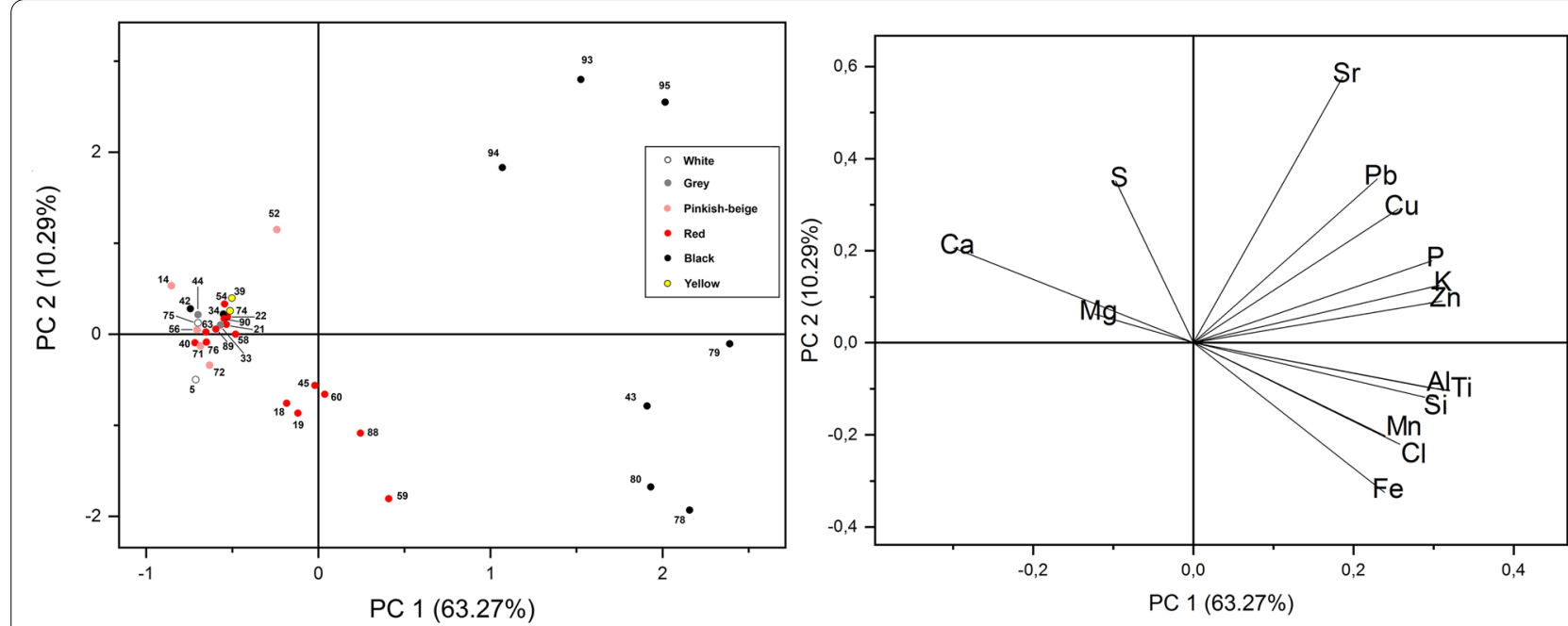

Fig. 6 Representation of the scores and loading plots for PC1 and PC2 of the dataset collected by hXRF in stone tesserae
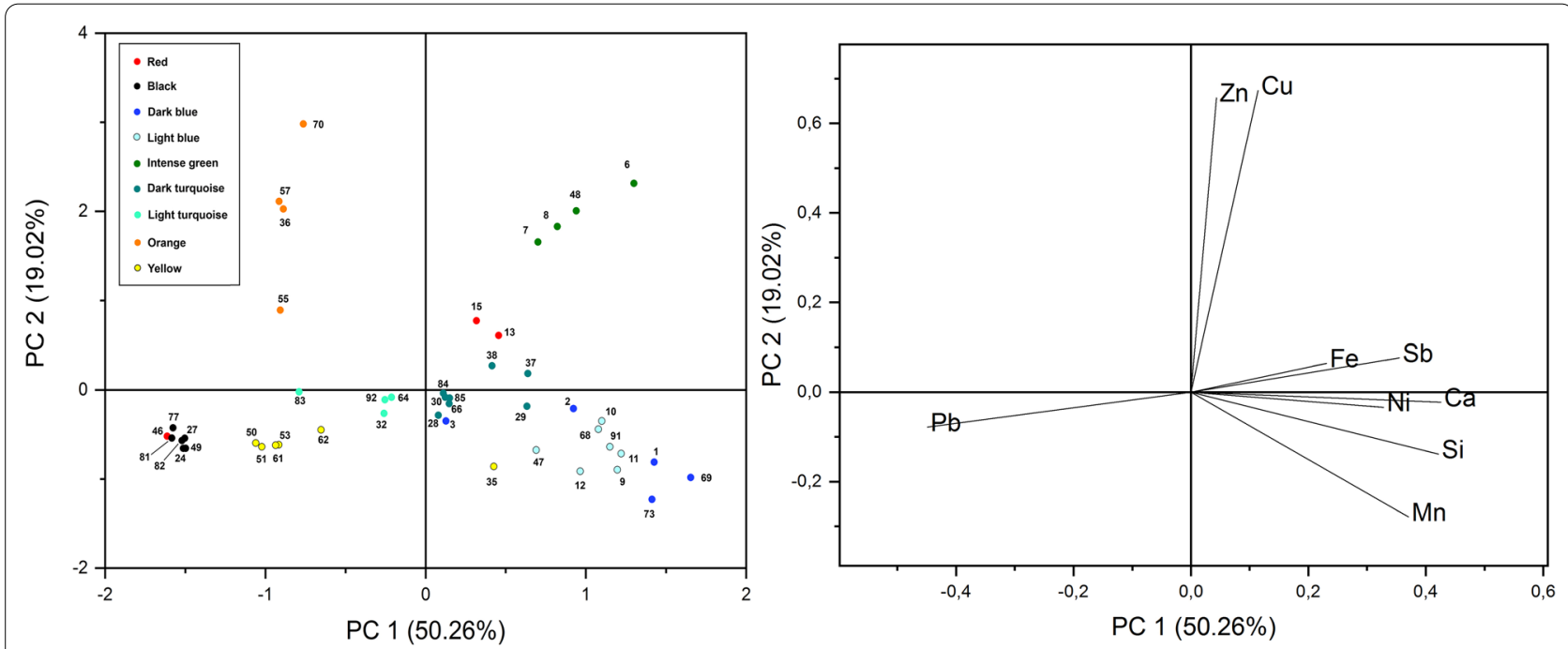

Fig. 7 Representation of the scores and loading plots for PC1 and PC2 of the dataset collected by hXRF in glass tesserae

$\mathrm{Ca}$, gives them a different profile to the other calcareous tesserae made with limestone (white and grey tesserae) (Fig. 9a).

\section{Red}

Twenty-one red tesserae, differentiated mainly by the intensity of their colour, were selected for study (Fig. 2e, f). Their Raman profiles, the PCAs (Figs. 4, 6, 7) and the $\mathrm{Mg} / \mathrm{Ca}$ ratios obtained in the hXRF analysis (Fig. 9) place them in three differentiated groups (Tables 1, 2, 3 and 4):

Group 1. Nine tesserae (18, 19, 20, 23 45, 59, 60, 87, 88) with Raman spectra that coincide with that of hematite $\left(\mathrm{Fe}_{2} \mathrm{O}_{3}, 224,291,410\right.$ and $609 \mathrm{~cm}^{-1}$ bands) (Fig. 8b) [50] and with a high Fe content. The PCA also classifies them differently (Fig. 6). The tesserae in this group would have been made from ironstone (Fig. 9b).

Group 2. Nine tesserae (21, 22, 40, 54, 58, 63, 76, 89, 90) that present the Raman spectra of calcite (bands ca. 154, 282, 711, $1086 \mathrm{~cm}^{-1}$ ) and higher Ca values than the rest of red tesserae. They would have been made from limestone rocks although some of them $(40,54,58,63,76)$ present a high enough $\mathrm{Mg}$ content to catalogue them in the dolomitic limestone rock category (Fig. 9c, d).

Group 3. In three tesserae $(13,15,46)$ (Fig. 9e) classified as vitreous in the grouping shown in Fig. 4, a particularity was detected based on the classification established by 

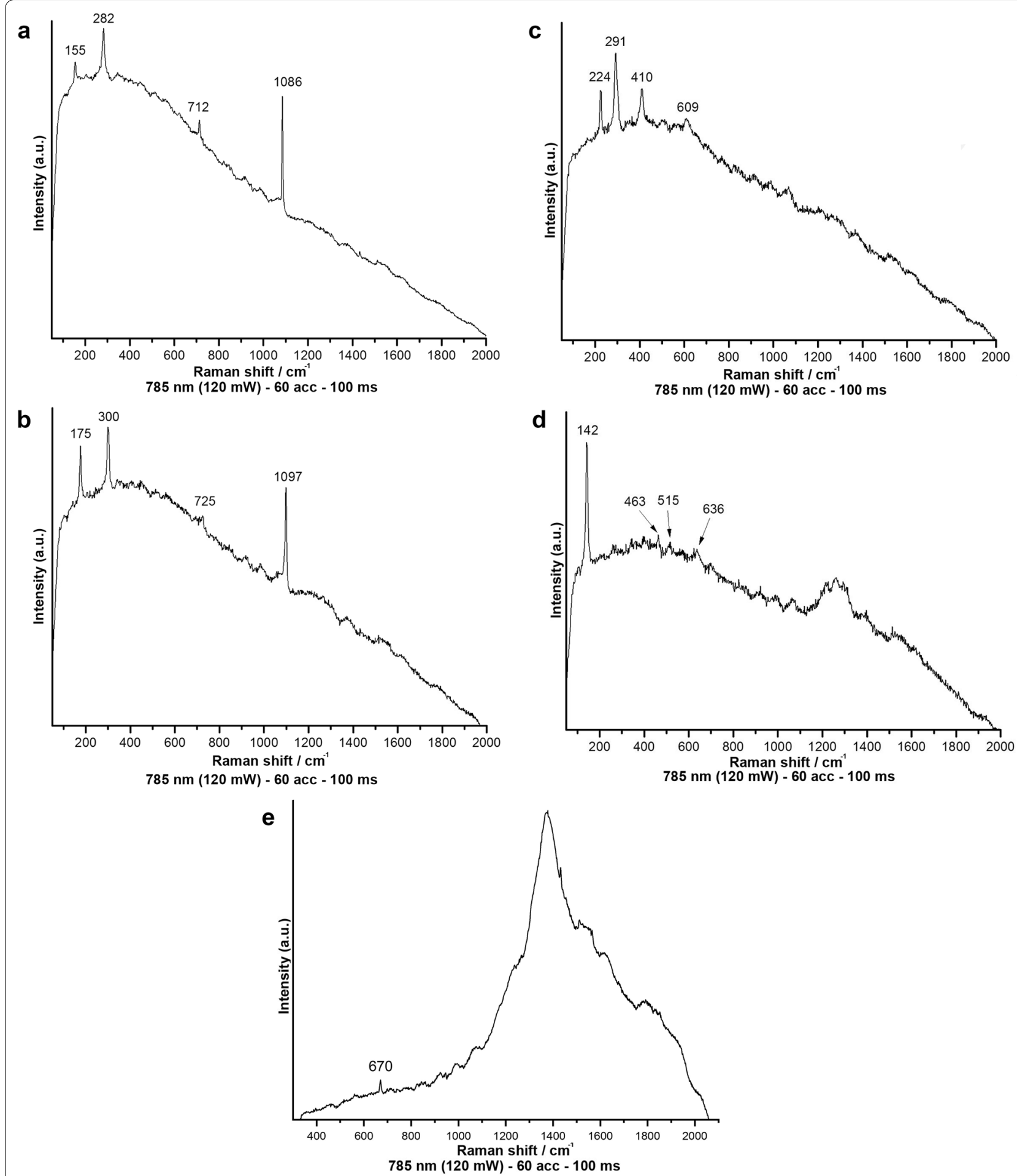

Fig. 8 Raman spectra. a Tessera 75, calcite. b Tessera 14, dolomite. c Tessera 59, hematites. d Tessera 43, anatase. e Tessera 9, calcium antimonate

the PCA of the glass tesserae (Fig. 7). Tesserae 13 and 15 present higher values of $\mathrm{Cu}$, indicating that this element acts as the chromophore in form of cuprous oxide $\left(\mathrm{Cu}_{2} \mathrm{O}\right)$ or metallic copper $\left(\mathrm{Cu}^{0}\right)$ [51]. In the case of Tessera 46, which is opaquer, the combination of $\mathrm{Cu}$ and $\mathrm{Pb}$ (acting as a stabiliser for colouring crystals) that was introduced 


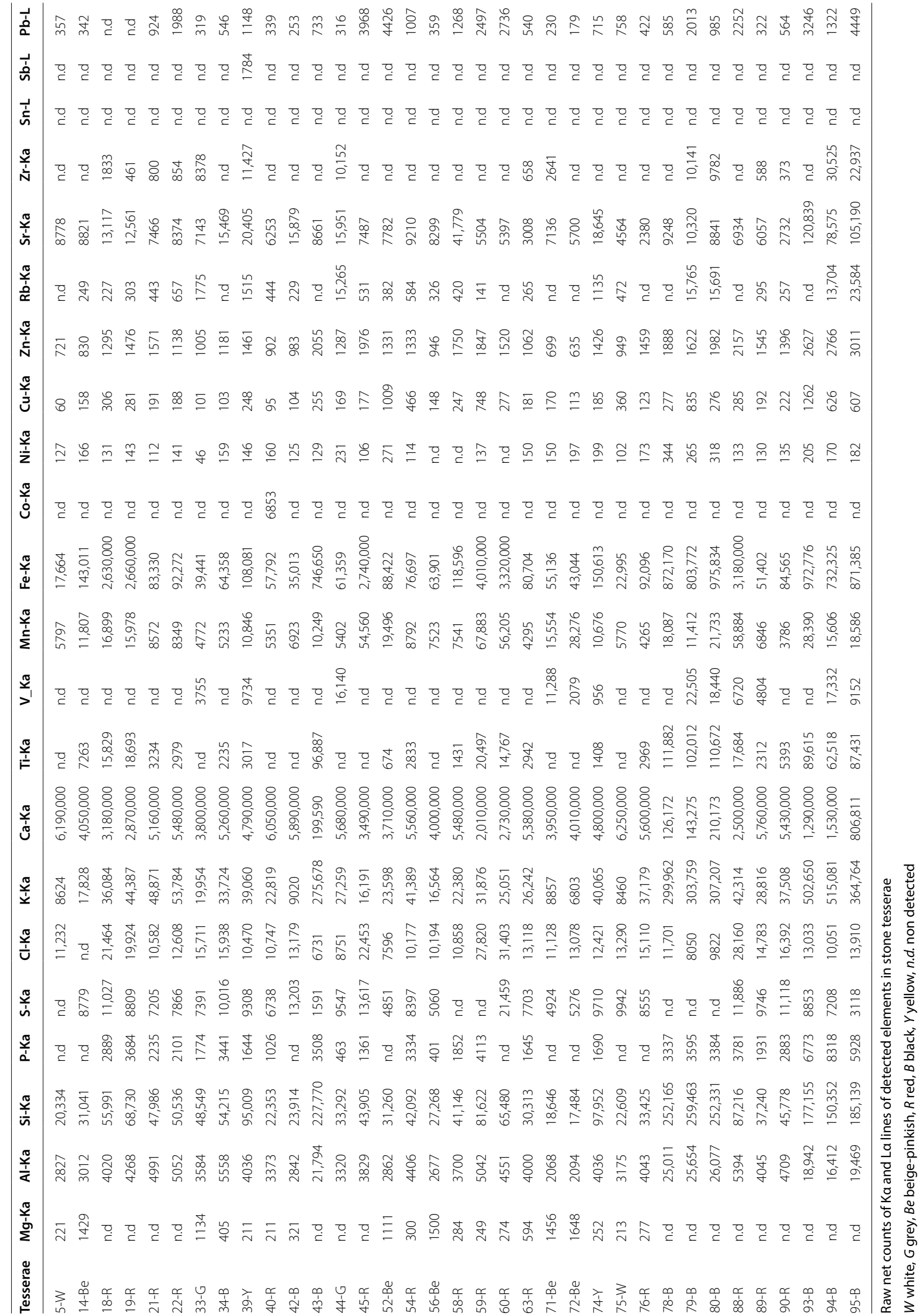




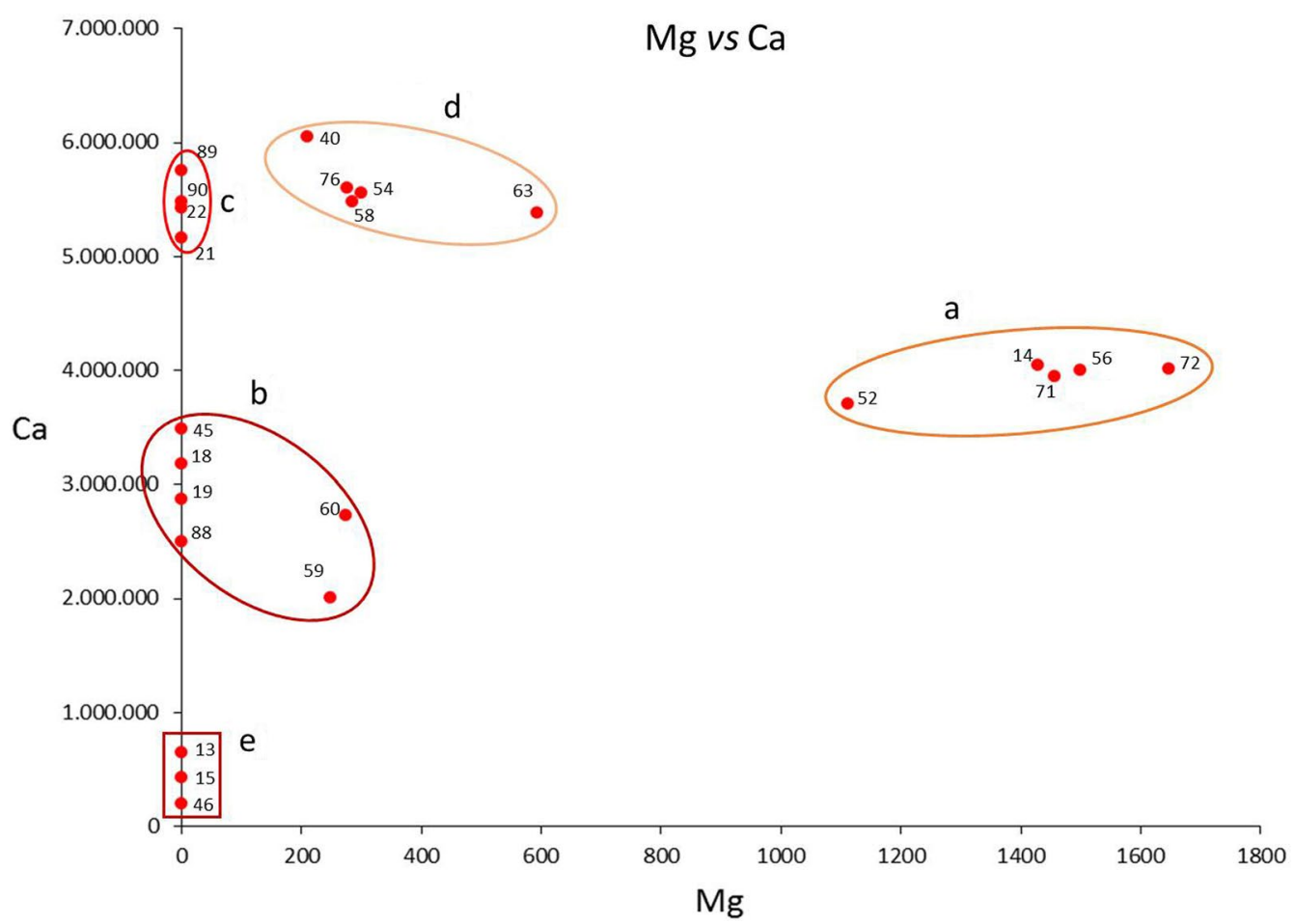

Fig. 9 Plot Mg/Ca of the red and pinkish-beige tesserae analysed in situ (raw net counts). a Dolomite. b Ironstone. c Limestone. $\mathbf{d}$ Dolomitic limestone. e Glass tesserae

into Roman tesserae from the first century AD on would explain that particular characterisation [52-54]. That notable presence of $\mathrm{Pb}$ would be the reason it is classified among the black lead tesserae. This notwithstanding, a second option aimed at cataloguing that tessera as a lead glass type would be feasible. In the future, a larger number of analyses of red tesserae of this type would be able to settle the question of their classification.

\section{Black}

Fifteen black tesserae were analysed. As mentioned above, there are black glass tesserae and black stone-type tesserae (Fig. 2g). A more detailed analysis of both categories allows us to identify 4 types according to their composition:

Group 1. Six glass tesserae with a high $\mathrm{Pb}$ content (24, 27, 49, 77, 81, 82) (Table 3) (Figs. 7, 10a).

Group 2. Two tesserae made of black limestone (34, 42). The Raman spectra of calcite and the high Ca values in the hXRF analysis validate this classification in both tesserae (Fig. 10b).

Group 3. Three tesserae $(93,94,95)$ manufactured from rock with a high $\mathrm{Si}$ and $\mathrm{Al}$ content (Figs. 6, 10c). They can be classified as coming from siliciclastic rocks and, considering the more than plausible presence of aluminosilicates, in the mudrock category, probably black shales [55].

Group 4. Four tesserae $(43,78,79,80)$, that judging by their high $\mathrm{Al}$ and $\mathrm{Si}$ values were also made from mudrocks, but with a considerable Ti content (Table 2) (Figs. 6, 10d), as reflected in the presence of the $140 \mathrm{~cm}^{-1}$ band associated with that oxide $\left(\mathrm{TiO}_{2}\right)$ (Table 1) (Fig. 8d). The presence of $\mathrm{Ti}$ is common in shales [56], meaning that this group could be a variation of the previous one.

\section{Blue}

The blue tesserae were made with vitreous paste and are differentiated in two groups according to whether their tonality is dark or light (Fig. 2h, i).

Group 1. The five dark blue tesserae analysed (1, 2, 3, 69,73 ) contain cobalt as the chromophore responsible for that colour (Table 3). It is usually added as Co(II) to the glass matrix of the tesserae by using some kind of mineral salt or another material rich in cobalt [31, 57-59]. It is known that the colouring power is five times greater than that of other transition metals: to produce a deep blue colour only a few hundred ppm are needed $[54,60]$. Despite the intensity of the blue provided by the cobalt, the values of $\mathrm{Sb}$ lead us to consider, as has been shown in other cases $[60,61]$, that calcium antimonate was added as an opacifier. 


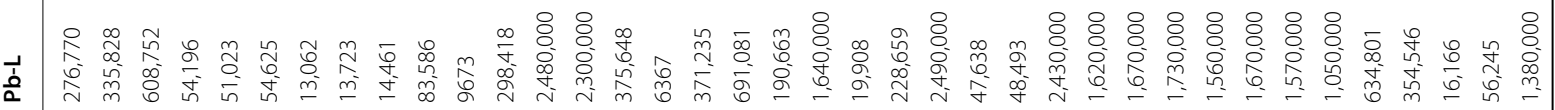

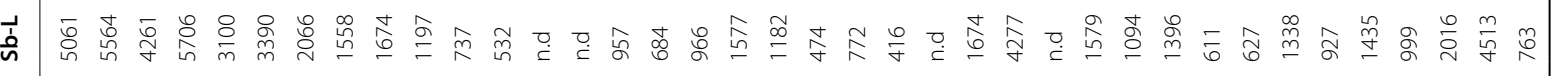

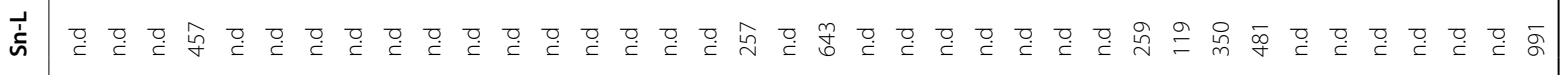

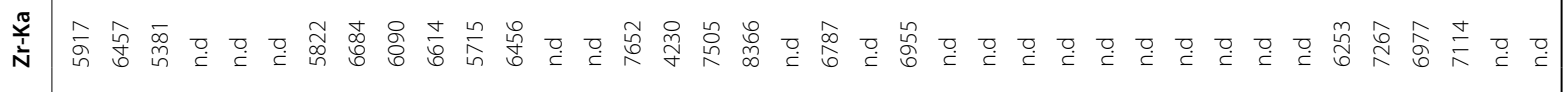

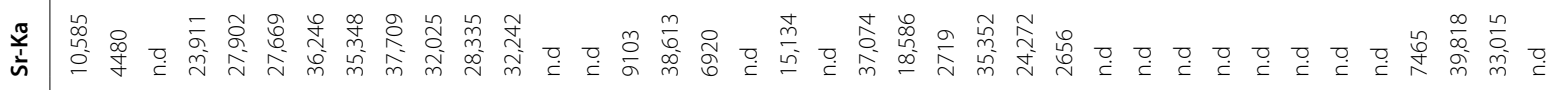
旁 站

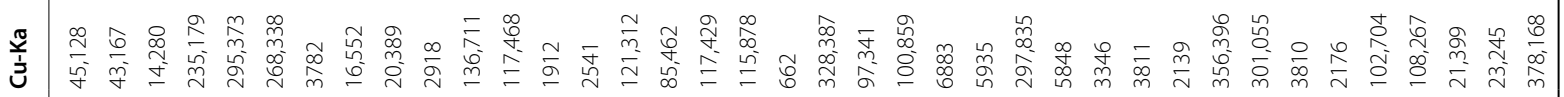

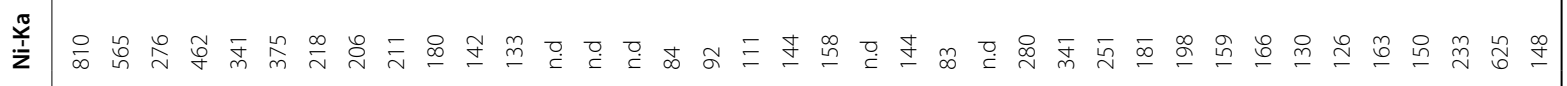

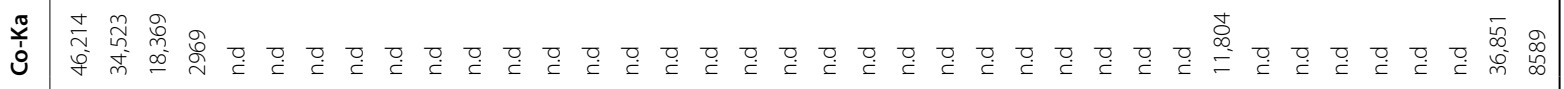
ஐ

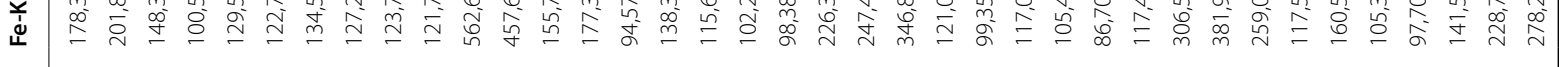

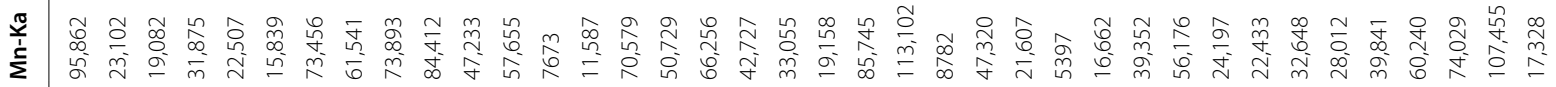
>

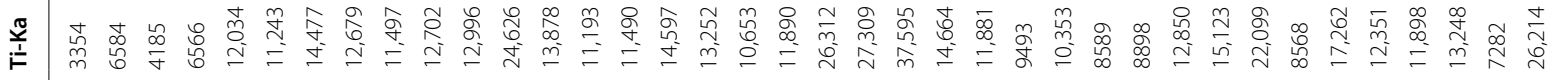
๘

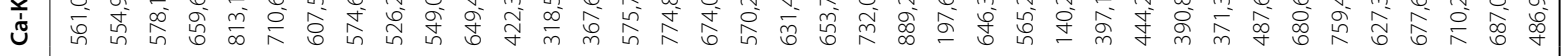

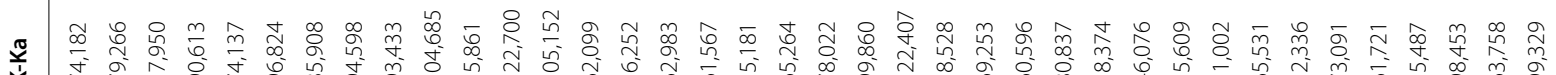

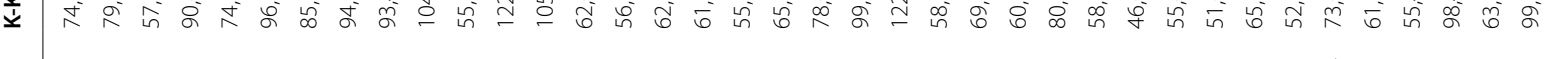
ஐ U

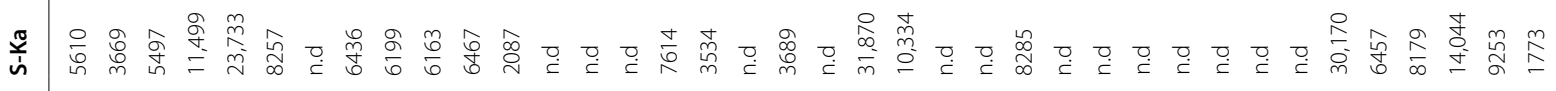

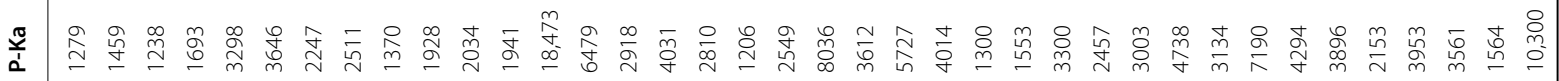

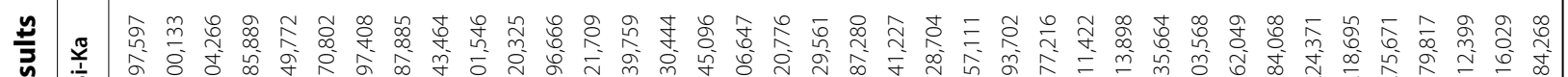
प्र

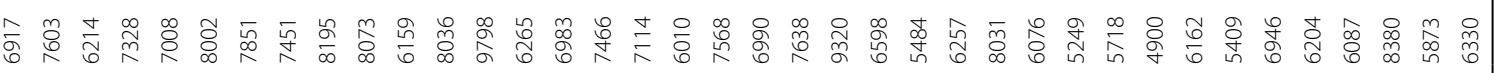




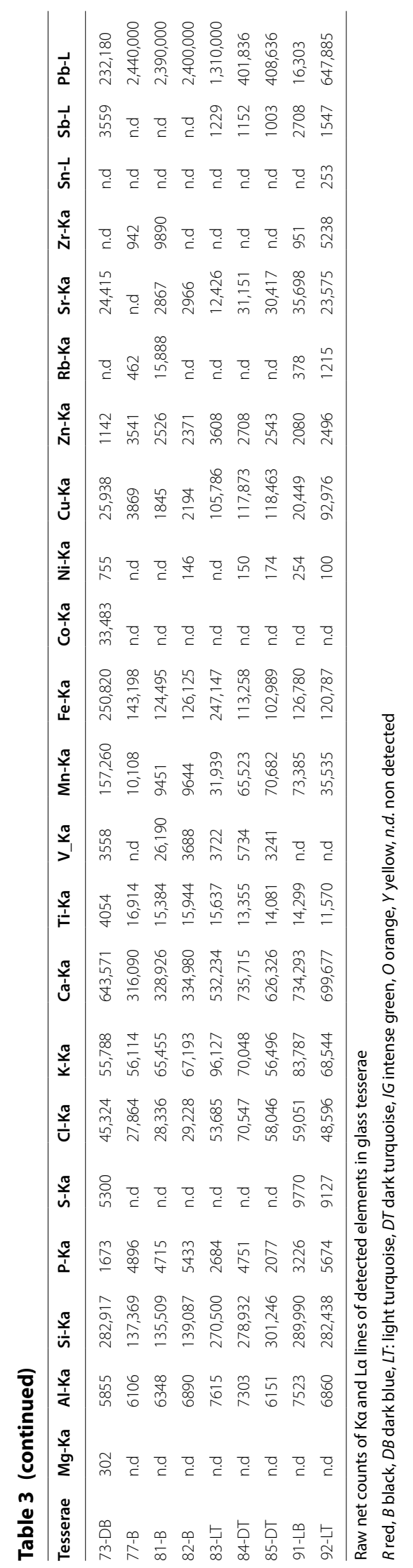


Table 4 Summary table

\begin{tabular}{|c|c|c|c|c|}
\hline Material & Colour & Characterization & Tesserae & Location \\
\hline \multirow[t]{10}{*}{ Stone } & White & Limestone & $5,41,75$ & Background of the scene and Hera's dress \\
\hline & Grey & Limestone & 33,44 & $\begin{array}{l}\text { Folds in Hera's dress, the stalks of the plant motifs } \\
\text { and the shadow of Hermes' foot }\end{array}$ \\
\hline & Beige & Dolomitic rock & $14,52,56,71,72$ & Skin and clothing \\
\hline & \multirow[t]{3}{*}{ Red } & Ironstone & $18,19,20,23,45,59,60,87,88$ & Clothing, the ear of an ox, the dog at Paris' side \\
\hline & & Limestone & $21,22,89,90$ & \multirow{2}{*}{$\begin{array}{l}\text { Clothing, the mouth of an ox, Paris' hand, Hermes' } \\
\text { hair, Athena's helmet }\end{array}$} \\
\hline & & Dolomitic limestone & $40,54,58,63,76$ & \\
\hline & \multirow[t]{3}{*}{ Black } & Limestone & 34,42 & Tree and the ox close to Paris \\
\hline & & Mudrocks (black shales) & $93,94,95$ & Heras' hair and outer perimeter around the scene \\
\hline & & Mudrocks (shales) $+\mathrm{TiO}_{2}$ & $43,78,79,80$ & Shadow lines of Aphrodite and Athena`s feet \\
\hline & Yellow & Silicified limestone & 39,74 & Hera's headwear, Athena's shield, one of the oxen \\
\hline \multirow[t]{10}{*}{ Glass } & Red & $\mathrm{Cu}(\mathrm{l})(\mathrm{chr})$. & $13,15,46$ & Paris' clothing and Hermes' chlamys \\
\hline & Black & Pb-rich glass & $24,27,49,77,81,82, \mathrm{BT}$ & Vegetable and clothing \\
\hline & \multirow[t]{2}{*}{ Blue } & $\begin{array}{l}\text { Dark blue: Co(II) (chr.) + Calcium antimonate } \\
\text { (op.) }\end{array}$ & $1,2,3,69,73$ & Paris and Hermes' chlamys \\
\hline & & $\begin{array}{l}\text { Light blue: } \mathrm{Cu}(\mathrm{II})(\mathrm{chr} .)+\text { Calcium antimonate } \\
\text { (op.) }\end{array}$ & $9,10,11,12,47,68,91$ & Paris, Hermes, Aphrodite, Athena and Hera \\
\hline & \multirow[t]{3}{*}{ Green } & Light turquoise: $\mathrm{Cu}(\mathrm{II})+$ lead antimonate (high) & $32,64,83,92$ & \multirow{3}{*}{$\begin{array}{l}\text { Clothes of Athenea and Aphrodite, and in } \\
\text { vegetable motifs (trees, schrubs) depicted near } \\
\text { Paris }\end{array}$} \\
\hline & & Dark turquoise: $\mathrm{Cu}(\mathrm{II})+$ lead antimonate (low) & $28,29,30,37,38,66,84,85$ & \\
\hline & & Intense green: $\mathrm{Cu}(\mathrm{II})$ & $6,7,8,48, \mathrm{GT}$ & \\
\hline & Orange & Cu from bronze and/or brass (chr.) & $36,55,57,70$ & $\begin{array}{l}\text { Hermes' chlamys and the apple, also found in } \\
\text { Athena's helmet and the dog at Paris' side }\end{array}$ \\
\hline & \multirow[t]{2}{*}{ Yellow } & \multirow[t]{2}{*}{ Lead antimonite (chr.) } & $50,51,53,61,62$ & Hera's headwear, in details on Hermes'head \\
\hline & & & 35 & $\begin{array}{l}\text { Paris' clothes and the frame around the Medusa's } \\
\text { head on Athena's breast }\end{array}$ \\
\hline
\end{tabular}

Colours and characterization of tesserae. chr. chromophore, op. opacifier, BT loose black tesserae, $G T$ loose green tesserae

Group 2. In the Raman spectrum, the group of light blue tesserae $(9,10,11,12,47,68,91)$ present the $670 \mathrm{~cm}^{-1}$ band characteristic of calcium antimonate (Fig. 8e), although no other intense bands (Table 1). In this group, $\mathrm{Cu}$ in its divalent state was used to produce a light blue colour in the translucent glass [54] (Figs. 7, 11a).

\section{Green}

We have identified three groups of green tesserae: light turquoise, dark turquoise and intense green (Fig. 2j, k, l). Their manufacture depends on the amounts of $\mathrm{Cu}$ and $\mathrm{Pb}$ added during the preparation of the tesserae vitreous paste [21, 24, 62-64]. The PCA was especially conclusive in the separation of intense green tesserae (Fig. 7).

Group 1. According to the hXRF analyses of the four tesserae $(32,64,83,92)$ (Table 3), the light turquoise colour would have been the result of a mixture in diverse proportions of $\mathrm{Cu}$ (blue chromophore) and $\mathrm{Pb}$ (yellow chromophore), present in the form of lead antimonate $\left(\mathrm{Sb}_{2} \mathrm{O}_{7} \mathrm{PbO}_{2}\right)$ [65]. The $\mathrm{Cu} / \mathrm{Pb}$ ratio would have caused a variation ranging from lightest turquoise (Tessera 83) to less light turquoise (Tesserae 32, 64, 92) (Fig. 11b) (Table 3).

Group 2. This same argument is valid for the dark turquoise tesserae $(28,29,30,37,38,66,84,85)$ (Fig. 11c). In this case, the reduction is based on the $\mathrm{Pb}$ values, resulting in tesserae with a darker, bluer tone due to the lack of the yellow chromophore.

Group 3. In contrast to the previous groups, the intense green coloured tesserae $(6,7,8,48)$ are characterised, according to the hXRF analysis, by the significant presence of $\mathrm{Cu}$ (Fig. 11d).

\section{Orange}

All the orange tesserae $(36,55,57,70)$ (Fig. $2 \mathrm{~m}$ ) were made of glass. In this case the chromophore agent was exclusively $\mathrm{Cu}$, a very common element in this type of tessera [21, 62]. This group recorded the highest $\mathrm{Cu}$ values of all the tesserae analysed from the Judgement of Paris. The small amounts of Sn and even of $\mathrm{Zn}$ they all displayed indicate a bronze and/or brass smelting product as a source for the $\mathrm{Cu}$-based colourant $[54,62]$ (Fig. 7) (Table 3). 


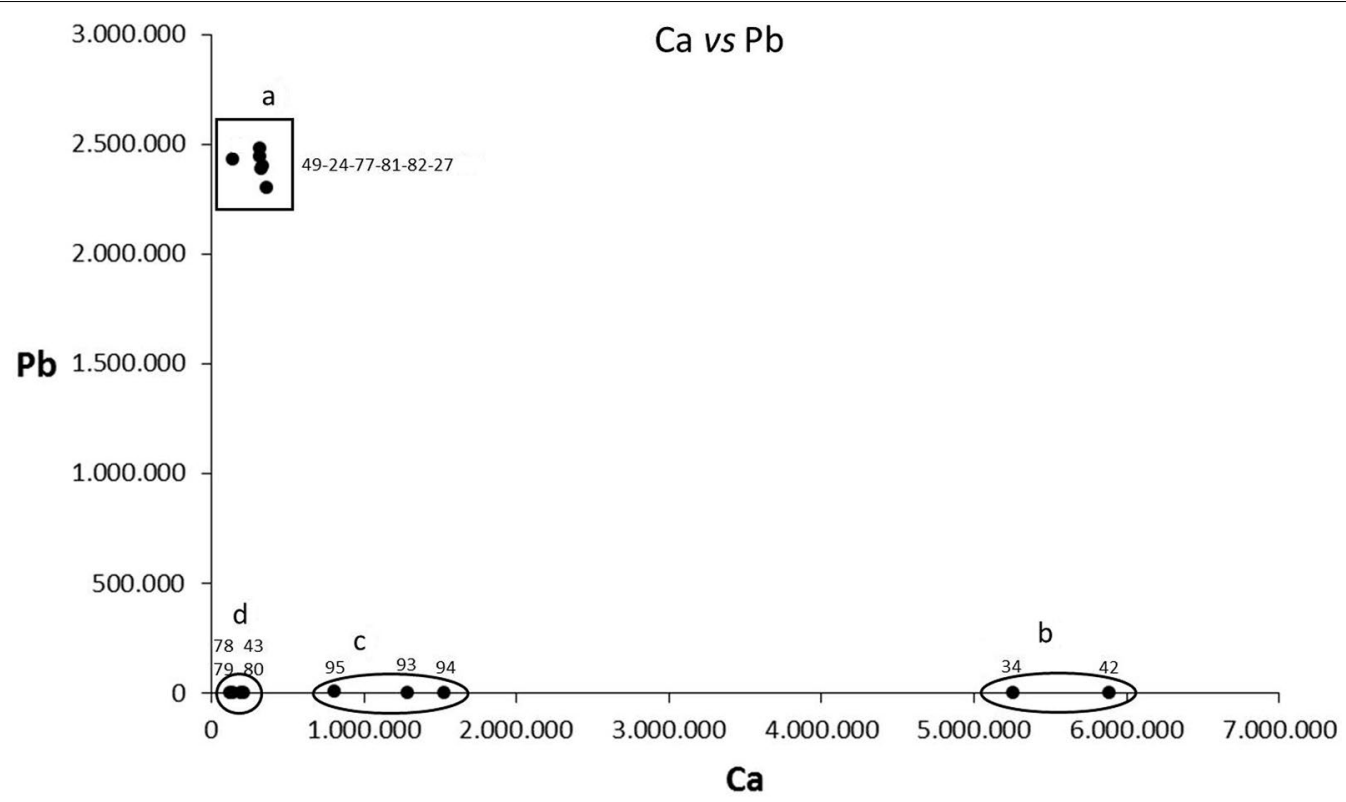

Fig. $10 \mathrm{Plot} \mathrm{Ca} / \mathrm{Pb}$ of the black tesserae analysed in situ (raw net counts). a Pb-glass paste. b Black limestone. c Black shales. d Shales with TiO 2

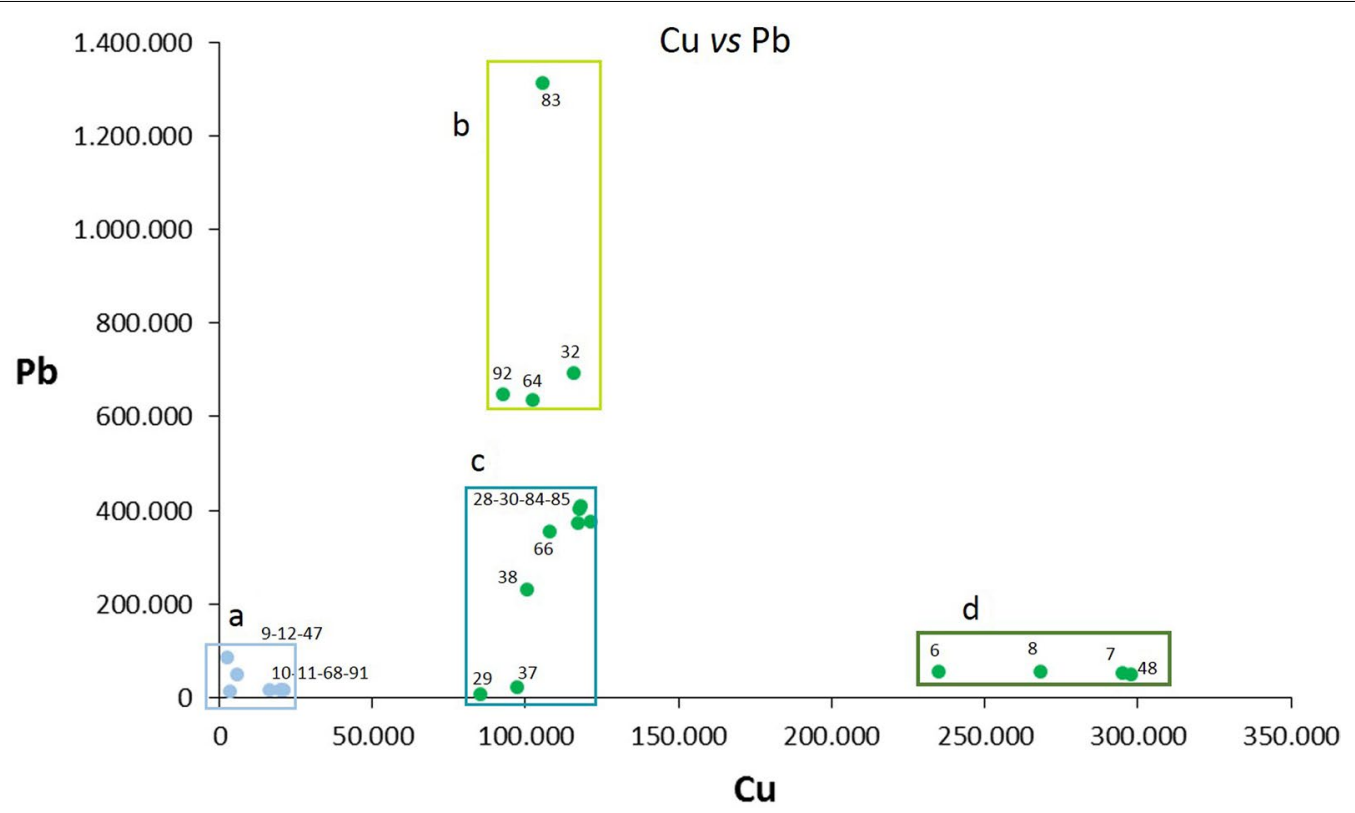

Fig. $11 \mathrm{Plot} \mathrm{Cu} / \mathrm{Pb}$ of light blue and green tesserae analysed in situ (raw net counts). a Light blue. b Light turquoise. c Dark turquoise. $\mathbf{d}$ Intense green

Yellow

This group presents two types of tesserae according to the yellow tonality and the raw material used (Fig. 2n, o). Two of them (39 and 74) with a mustard-yellow tonality were made of limestone with an appreciable presence of $\mathrm{Si}$. In fact, these are the limestone tesserae with the largest Si content of all those analysed in the mosaic. The Raman spectra of both samples were not conclusive, but the hXRF analysis indicated a significantly higher $\mathrm{Ca} / \mathrm{Si}$ ratio (Fig. 12a).

The rest of the yellow tesserae $(35,50,51,53,61,62)$ are shinier and made of glass. Raman spectra was not 


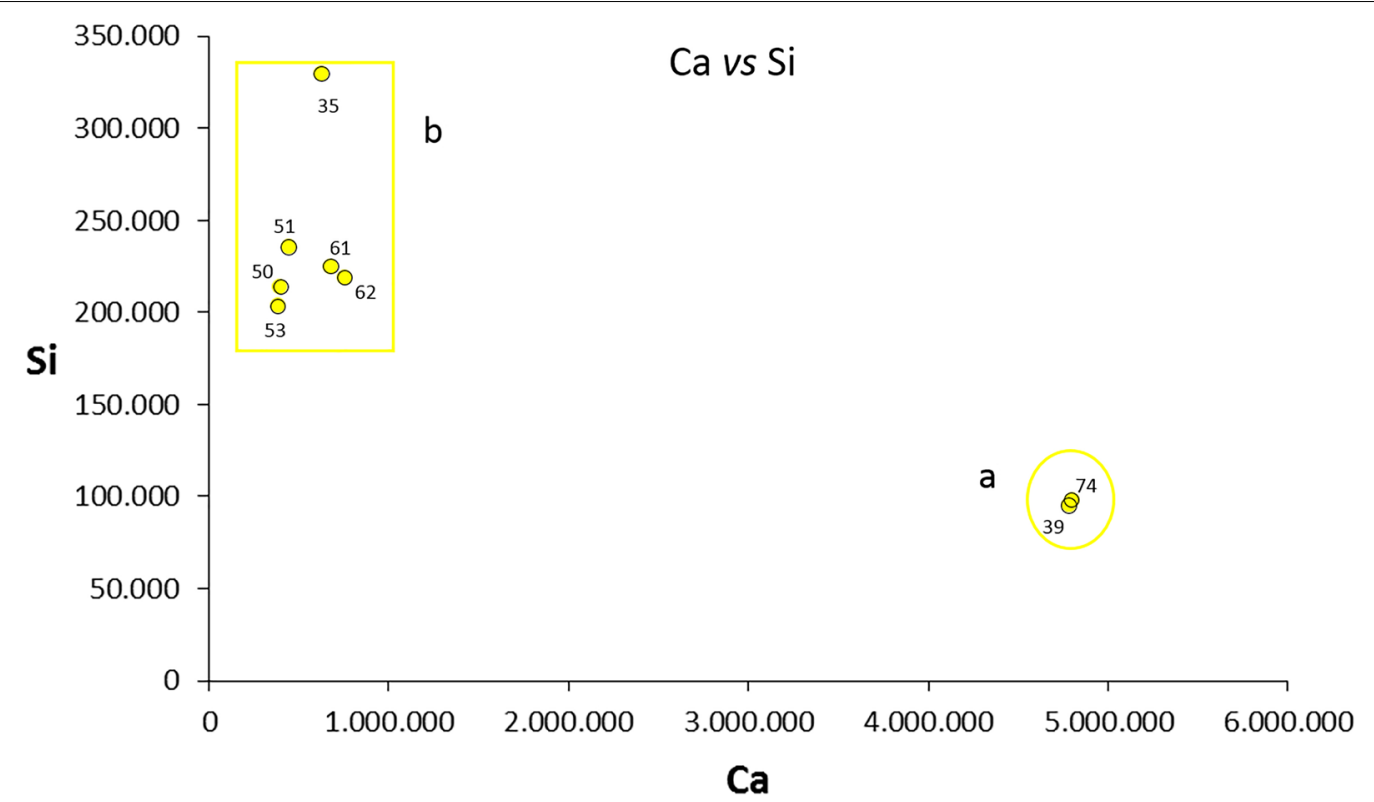

Fig. 12 Plot Ca/Si of the yellow tesserae analysed in situ (raw net counts). a Stone. b Glass

conclusive (Fig. 7), but, judging by the values of $\mathrm{Pb}$ and $\mathrm{Sb}$ present, lead antimonate must be considered their main colouring agent $[66,67]$ (Table 3) (Figs. 7, 12b). In this group, the composition of Tessera 35 shows a lower $\mathrm{Pb}$ content, which produces a type of tessera with a more matt, less glossy tone [67]. In general, although the origin of the lead antimonate is difficult to establish, different studies have proposed various options, among which the most likely are galena for the $\mathrm{Pb}$ and stibnite for the $\mathrm{Sb}$ $[60,67]$.

\section{Discussion}

Several aspects can be highlighted from the results presented, both from a methodological point of view and from an archaeometric and archaeological perspective.

\section{Assessment of the methodology}

The procedure followed is not exempt from the problems inherent to both techniques. Fluorescence background is a limiting factor in the use of MRS and, in the case of portable equipment, this is even more acute, especially when analysing glass tesserae [68-70]. The incorporation of loose tesserae and their analysis using high-resolution, large spectral window instruments can, in part, overcome this handicap.

In the case of the hXRF analysis, one of the clearest limitations is the detection of low $\mathrm{Z}$ elements (due to the strong absorption of low energy $\mathrm{X}$-rays by air and by the Be window of the detector) [40, 41] Adlington 2017 y 2020. The inability of hXRF equipment to generate high vacuum hinders its ability to correctly detect and quantify these elements. This problem affects particularly important elements such as $\mathrm{Na}$, which is commonly present in glass and is necessary for assessing the manufacturing and degradation processes of this material [25, $26,71]$. Thanks to the two-beam $(40$ and $10 \mathrm{kV})$ measurement mode of the Olympus ${ }^{\mathrm{TM}}$ Innov-X Delta Premium instrument, it was possible to measure major low- $\mathrm{Z}$ elements [28].

Although the tesserae were fairly well preserved and were cleaned to remove any attached dirt or dust, we should not ignore the fact that some of them may have undergone superficial physical, biological and chemical alterations (especially those made from carbonate rocks) that could affect the measurements [72]. However, in cases of initial degradation, the penetrating power of the $\mathrm{X}$-Ray beams used in this study, that is often considered a limitation for the use of the XRF technique in purely superficial measurements, would allow obtaining information of the chemical composition below the external surface.

Despite the aforementioned limitations, the impossibility of obtaining a representative number of detached tesserae and the need to maintain the integrity of the mosaic made it necessary to instigate an in-situ analytical strategy that, judging by the results obtained with the Judgement of Paris, has been effective.

The analysis of tesserae revealed the intrinsic difficulty of selection according to colour. Subjective as it may appear, the analysis based on objective, physical and 
chemical parameters bring to light issues in the chromatic criterion. Thus, tesserae initially selected according to well-differentiated shades (two shades of red, two shades of yellow and one black), reveal different chemical compositions that eventually lead to a more fine-grained classification: three shades of red, three shades of yellow and four shades of black. By contrast, tesserae that are clearly different in colour may reveal, upon analysis, the use of the same raw material (e.g. pink tesserae made of dolomites).

\section{Stone tesserae}

The in-situ analysis has not allowed us to perform petrological analysis on the Judgement of Paris, but the results obtained in the MRS and hXRF analyses of the stone tesserae have provided an enough level of detail to propose a first classification into three categories (Table 4):

- Carbonate rocks. Within this type we differentiated limestones of various colours (black, white, grey and red tesserae), silicified limestone (yellow), dolomitic limestones (grey, red tesserae), dolomites (beige/pink tesserae).

- Siliciclastic rocks. This group of rocks includes the mudrocks with the presence or absence of Ti for the black tesserae.

- Ironstone. This rock category includes the red tesserae with a recurring and abundant presence of hematite.

Of all the types of stone used, the most abundant are from carbonate rocks, particularly limestone, a type widely used in all the analysed mosaics dated between the second and the fifth centuries AD in the Mediterranean area $[26,44,67,73]$. This type of rock is easy to cut, as it has a very compact texture and low porosity, thus facilitating the work of the artisans. To this property we have to add the uniformity of colour, a very important aspect for the creation of the mosaic, both for the composition of the figures and for the geometries, given that any veins in the tesserae deform their colouring and the portrayal. Another important characteristic of this material is the ease with which it can be polished to achieve a relatively smooth, non-shiny surface for the mosaic [74].

Regarding the possible origin of the stone tesserae, Cástulo is located in a geologically diverse region with a variety of sedimentary rocks, including conglomerates, limestones, dolomites, sandstones and granite outcrops $[28,75]$. With this in mind, it is quite likely that the mosaic artisans made the stone tesserae using the various types of rocks available in the nearby territory of Cástulo. Particularly interesting is the identification of the use of ironstone to make numerous red tesserae. The use of this raw material is practically unknown in most of the Roman mosaics analysed in Europe. Exceptions include those from Complutum (Alcalá de Henares, Spain) [76] and Pompeii, although in the latter it is an imitation with limestone tesserae decorated with a layer of the reddish iron oxide mineral [26]. In the case of Cástulo, its use appears to indicate ease of access to this type of rock and, therefore, an especially differentiating aspect of the Los Amores Mosaic. Outcrops of ferruginous minerals in the Upper Guadalquivir and the surrounding mountains are common and their exploitation to obtain metal, pigments and building materials has been documented since Prehistory $[77,78]$.

Given that the majority of the stone tesserae are made from carbonate rocks (limestone and dolomite), they are susceptible to physical alteration due to the formation of soluble salts, fractures caused by thermal factors, the development of biological patinas (lichens), and chemical changes caused by dissolution in an acidic medium. In unpolluted environments, such as that of Cástulo, the acidity would have been caused by carbonic acid formed by the dissolution of rainwater in atmospheric $\mathrm{CO}_{2}[72$, 79-81].

\section{Glass tesserae}

Concerning the glass tesserae, in addition to identifying at least two types of glass used, this research has been able to study a considerable number of tesserae and obtain information about seven colour types (black, red, blue, turquoise, green, orange and yellow) (Table 4), the chromophore agents and opacifier used:

- Cobalt $\left(\mathrm{Co}^{++}\right)$for dark blue.

- Copper for light blue $\left(\mathrm{Cu}^{++}\right)$, red $\left(\mathrm{Cu}^{+}\right.$or $\left.\mathrm{Cu}^{0}\right)$ and orange (metallic copper likely obtained from bronze and/or brass).

- Copper $\left(\mathrm{Cu}^{++}\right)$for greens and copper and lead antimonate for turquoises.

- Lead antimonate for yellow.

- The opacifier identified was calcium antimonate which is found mainly in the green, dark and light blue.

This expansion of the colour repertory investigated is particularly important, as yellow, orange and red tesserae had not been analysed in the studies of vitreous tesserae from pre-fourth-century-AD Spanish mosaics [44, 8287]. Although the information provided by hXRF does not allow any definitive conclusion to be reached about the source of the glass used in any of the tesserae (local or of eastern Mediterranean origin) [88], it is interesting to point out the case of the lead tesserae. The surrounding area and the mountains north of Cástulo are renowned 
for their rich $\mathrm{Pb}-\mathrm{Ag}$ ore mineral veins. Cástulo was a major source of the extraction and management of the Upper Guadalquivir's mineral riches between the second century $\mathrm{BC}$ and the second century $\mathrm{AD}$. The proximity of the lead mining areas and the presence of black vitrified lead slags on the surface of Cástulo suggest local manufacture. This proposal, which would challenge the model of specialized glass-colouring workshops, will be subject to verification with the expansion of the mosaic study and the analyses of the vitrified black fragments collected.

The important collection of glass tesserae identified also hints the most common pathologies associated with archaeological glass objects, such as craters and dealkalisation layers. The former are frequent and tend to appear as small spherical or oval holes that may eventually merge. Some are visible in the detached green tesserae under analysis (Fig. 5a). Dealkalinisation causes iridescent silica gel layers on the surface and is associated with phases of humidity and dryness. This humid/arid cycle would have affected the microstructure of the glass, giving rise to physical stresses that would have eventually fractured and separated the surface layers $[83,89]$.

\section{Selection of colours}

Another aspect to emerge from the analyses is the choice of the colour for each figure and the types of tesserae used to obtain it. The selection or intentional use for symbolic or practical reasons of tesserae in certain parts of the scene is contradictory and irregular. In some cases, it is to maintain specific identifying signs in the figures; in others it appears that a shortage of some colours compelled the use of similar pieces.

In general terms, stone tesserae were mainly used in the background of the scene, on animals and on some clothing and bodies. The vitreous tesserae were used for specific items of clothing characteristic to each figure, as well as on complements and plant motifs.

More precisely, the use of white in the figure of Hera on a background of white limestone tesserae can only be explained by the fact that white is a colour associated with that goddess. The same is true of Hermes, whose chlamys was depicted in red and orange tones from the fifth century $\mathrm{BC}$ on. The turquoise tesserae that make up Venus' clothing, which is normally silk, are also intentional. Centuries later, the mosaics of Casariche (Seville), Antioch (Turkey) and even Noheda (Cuenca) repeat wholly or partially the decorative schemes seen in Cástulo $[14,16,18]$.

In other cases, the composition of a colour was achieved by combining tesserae made with different materials. The reason for this could be explained on artistic grounds, the deliberate exploitation of the different optical properties of the material, random selection of tesserae or an attempt to make up for a shortage of certain types. The case of the red, black and yellow tesserae is quite clear in this respect. In the red decoration of Hera's chest, we identified red limestone (89) and ferruginous origin (88) tesserae. The black tesserae used on the lines of Venus' dress contain a combination of glass (81 and 82) and black mudrock tesserae (80). In the case of the yellow tesserae, whereas Hera's headwear is created with silicified limestone and glass paste tesserae, the frame around the Medusa's head is a combination of two types of glass tesserae (Fig. 13).

Faced with the difficulty of establishing the origin of the glass tesserae from the hXRF data, the combination of glass and stone tesserae is of some help when it comes to the question of their supply and their possible foreign origin. The artisans responsible for the manufacture of tesserae, probably from an itinerant workshops operating in different areas of Andalusia [9], did not have a regular supply of glass tesserae. This could indicate a foreign rather than a local origin, otherwise they would not have had to substitute them in some places with other types of a similar appearance (yellow tesserae) or those made of stone (yellow, red and black tesserae). We will be able to reach more detailed and in-depth conclusions regarding these hypotheses when we evaluate all the analysed tesserae from the Los Amores Mosaic.

\section{The Cástulo workshop}

The particularity of some of the raw materials used in Cástulo calls for some considerations and explanations regarding the existence of schools and workshops specialising in the manufacture of mosaics in the south of the Iberian Peninsula. Research into the artistic and iconographic aspects has identified in this region a school with its main focus around the Guadalquivir (from Córdoba to the river mouth). The Cástulo mosaic shows iconographic and stylistic similarities that have favoured proposals to include it in that school, although represented by a differentiated, itinerant workshop operating in Jaén province from the second century $\mathrm{AD}[6,9]$.

The data obtained from the archaeometric analysis supports this hypothesis if we compare it with other studies of mosaics in Andalusia of a similar chronology. Mosaics from Cártama (Málaga), Itálica (Seville), Carmona (Seville), Puerto Real (Cádiz), Écija (Seville) and Málaga have been chemically and petrographically analysed and all have been dated to between the second and the third centuries. Most of the results obtained from their study only refer to stone tesserae, in which limestone of various colours (white, red, black and yellow) is the predominant raw material, together with some tesserae manufactured with sandstone, volcanic rocks and pottery $[44,82-87]$. To this group we could 


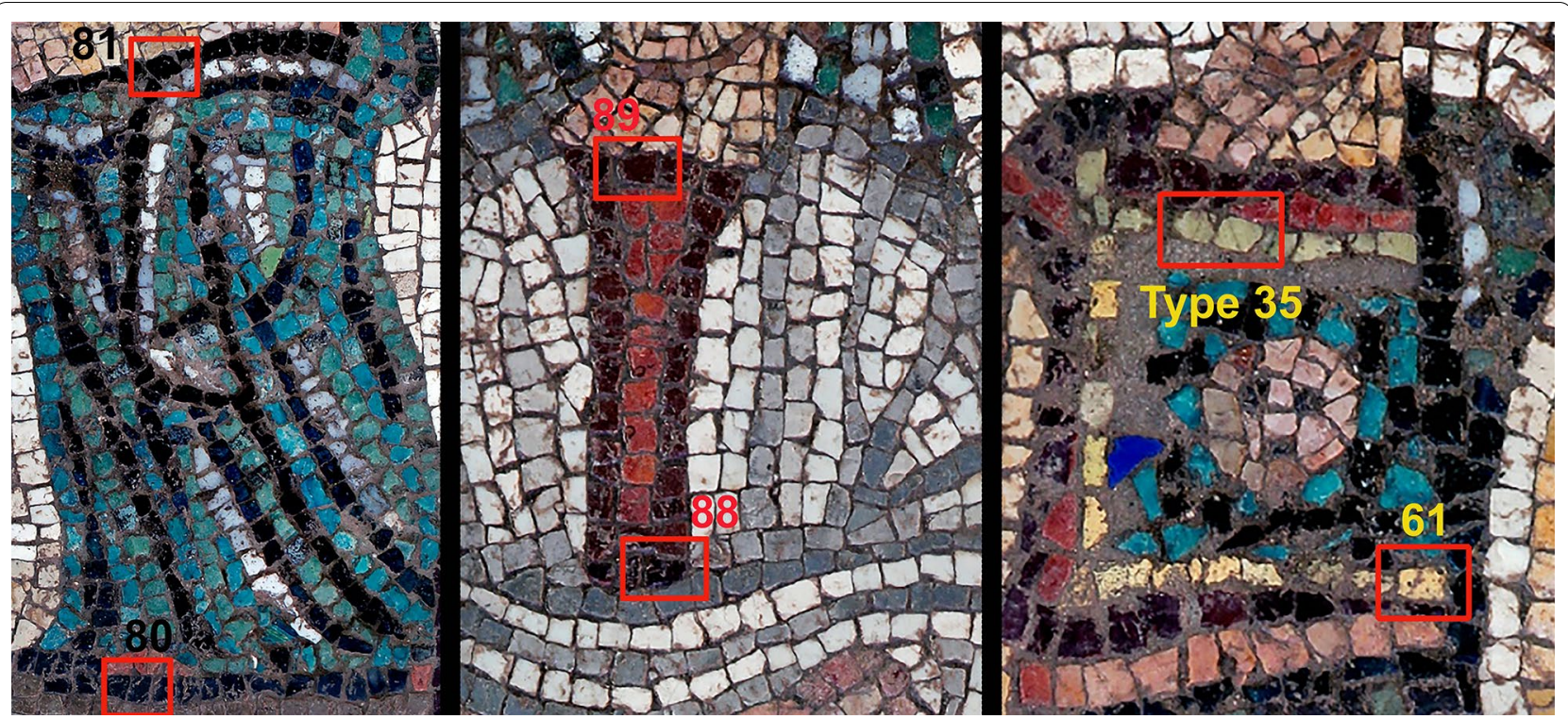

Fig. 13 Details of Aphrodite, Hera and Medusa's head on Athena (from left to right)

add the mosaics from the Maritime Baths at Baelo Claudia (Cádiz), although their chronology remains undefined between the second and the fourth centuries AD [90].

The only thing the Judgement of Paris mosaic has in common with the previously mentioned examples is the use of diverse types of carbonate rocks, as there are no tesserae made with sandstone, volcanic rocks or pottery. As an example of the particularity of this mosaic and as a possible expression of the aforementioned workshop operating in Jaén province, of particular note are the tesserae made with dolomite, siliciclastic rocks and, above all, the previously mentioned ironstone.

Data referring to glass tesserae in the south of Spain are much sparser and it is difficult to make comparisons. Only twelve blue and green tesserae from the mosaics of Itálica and Cármona with $\mathrm{Cu}$ and Fe identified as chromophore agents belong to this period [83, 87]. In Cástulo, on the other hand, it has been possible to study one of the most comprehensive repertoires on the Iberian Peninsula. One differentiating element of this hypothetical workshop, which would have to be confirmed with further research into glass tesserae, would be the use of the aforementioned lead tesserae. The use of this type of glass has not been documented in the archaeometric analyses undertaken on the Iberian Peninsula, either in mosaics contemporary to Los Amores Mosaic or in those to which later datings are attributed [17, 18, 83, 87]. This singularity, linked to the types of stone tesserae, would therefore add credence to the stylistic and iconographic identification of a workshop of artisans who would have been operating in the Upper Guadalquivir with Cástulo as their main place of work.

\section{Conclusions}

The results achieved in this study are mainly important in several respects. A particularly relevant aspect with significant repercussions is related to the effectiveness of in situ analysis using portable non-invasive spectroscopic techniques. Despite the aforementioned limitations, the quantity and quality of the information obtained justifies its use. This is especially interesting for overcoming problems caused by the shortage of loose tesserae and for tesserae sampling based only on colour types.

The results obtained from the mineralogical and elemental analyses of the tesserae in the Judgement of Paris position the Los Amores Mosaic as a benchmark for our knowledge of the stone or vitreous raw materials, chromophores and opacifiers used in creating the mosaics of Roman Hispania. There are no archaeometric studies on the Iberian Peninsula of mosaics dated between the late first and third centuries AD that can offer such a full and varied catalogue of materials as the Los Amores Mosaic. In it we find the combination of stone and glass tesserae. The latter were mainly of the alkali-silicate glass type, although some of the black tesserae were also found to have been made of lead glass.

The characterisation undertaken is of special importance, as the dissemination, conservation and restoration strategies have to take this information into 
account. Of particular note is the combination of tesserae of the same colour manufactured with similar glass and stone as a consequence of the scarcity of certain types of tesserae. It is also important because more mosaics have been excavated in other rooms of Building $\mathrm{D}$ and it may be possible in the future to establish similarities and differences between the diverse types, depending on their location and the importance of the area. Finally, the proposal for a workshop of mosaic artisans operating in the Upper Guadalquivir and Cástulo, open a new line of archaeometric and archaeological research.

\section{Supplementary Information}

The online version contains supplementary material available at https://doi. org/10.1186/s40494-021-00483-7.

Additional file 1: Figure S1. a Location of Cástulo (Linares, Spain). b Virtual reconstruction of Cástulo city at Roman times. c Building D with Los Amores Mosaic. Figure S2. Los Amores mosaic in Cástulo (Linares, Spain). Figure S3. Areas 1, 2, 3 and 4 of Judgement of Paris in Los Amores mosaic. Figure S4. In situ analysed tesserae of Judgement of Paris in Los Amores mosaic (Area 1). Figure S5. In situ analysed tesserae of Judgement of Paris in Los Amores mosaic (Area 2). Figure S6. In situ analysed tesserae of Judgement of Paris in Los Amores mosaic (Area 3). Figure S7. In situ analysed tesserae of Judgement of Paris in Los Amores mosaic (Area 4).

\section{Acknowledgements}

The authors thank the Project Cástulo, Investigación arqueométrica y transferencia social (HAR2016-74917-R), the Archaeological Area of Cástulo (Linares, Spain), the CICT of University of Jaén and the SCAI of University of Málaga. M. Costa acknowledges Fundação para a Ciência e a Tecnologia for a Ph.D. Fellowship (SFRH/BD/128889/2017) co-funded by the European Social Fund and by Portuguese national funds. A. Rousaki acknowledges the Research Foundation Flanders (FWO-Vlaanderen) for her postdoctoral fellowship (12X1919N).

\section{Authors' contributions}

JT, AS, MM. and PV: coordination, conceptualization, wrote the main manuscript texts and analysed the overall results. BC and PA: selected samples, prepared figures, tables and analysed the results. JT and AS: conducted EDXRF and analysed the results. MM and PA conducted portable MRS and analysed the results. AR, SL, DS and MC: conducted handheld XRF and analysed the results. All authors read and approved the final manuscript.

\section{Funding}

This study was funded by Project Cástulo: Investigación arqueométrica y trasferencia social (HAR2016-74917-R) and University Research Institute for Iberian Archaeology (University of Jaén, Spain).

\section{Availability of data and materials}

All data generated or analysed during this study are included in this published article (and its supplementary information files).

\section{Competing interests}

The authors declare that they have no competing interests.

\footnotetext{
Author details

${ }^{1}$ University Research Institute for Iberian Archaeology, University of Jaén, Jaén, Spain. ${ }^{2}$ Department of Physical and Analytical Chemistry, University of Jaén, Jaén, Spain. ${ }^{3}$ Raman Spectroscopy Research Group, Department of Chemistry, Ghent University, Gent, Belgium. ${ }^{4}$ Archaeometry Research Group, Department of Archaeology, Ghent University, Gent, Belgium. ${ }^{5}$ HERCULES Laboratory, University of Évora, Évora, Portugal.
}

Received: 29 July 2020 Accepted: 7 January 2021

Published online: 22 January 2021

\section{References}

1. Choclán C. Cástulo: radiografía de un territorio. In: Leis V, Martínez L, Rabaneda L, coordinators. Actas I Congreso de Historia de Linares. Jaen: Centro de Estudios Linarenses, Diputación Provincial de Jaén; 2012. p. 29-47.

2. Castro M. Cástulo municipio romano. Esfinge. 2018;67:12-4.

3. Jiménez JA, Sales J. Termas e iglesias durante la Antigüedad Tardía: ¿reutilización arquitectónica o conflicto religioso? Algunos ejemplos hispanos. In: Blázquez, JM, Martínez, González A, editors. Antigüedad y cristianismo: Monografías históricas sobre la Antigüedad Tardía. Murcia: Universidad de Murcia; 2004. p. 185-202.

4. Castro M, Arias F, Serrano L, Martínez AL, Serrano M. Cástulo in the 21st century: a test site for a new digital information system. In: Averett $E$, Gordon JM, Counts DB, editors. Mobilizing the Past for a Digital Future: The Potential of Digital Archaeology. Grand Forks, ND: The Digital Press at the University of North Dakota; 2016. p. 319-35.

5. Jiménez Y. El posible edificio de culto imperial. Una reflexión forzosamente penúltima. 7 esquinas 2014; 6: 89-103.

6. López G. El mosaico de los Amores de Cástulo. 7 esquinas 2014; 6: $117-26$.

7. Tuñón J, Sánchez A, Parras DJ, Amate P, Montejo M, Ceprián B. The colours of Rome in the walls of Cástulo (Linares, Spain). Sci Rep. 2020. https://doi. org/10.1038/s41598-020-69334-y.

8. Castro M. Avatares constructivos de la sala del mosaico de los Amores. 7 esquinas 2014; 6: 127-28.

9. San Nicolás P. Un taller musivo en Jaén (España). Espacio Tiempo y Forma. 2018. https://doi.org/10.5944/etfii.31.2018.22658

10. Cristóbal V. La Eneida de Virgilio, un viaje entre Troya y Roma. Revista de Filología Románica 2006; anejo IV: 85-100.

11. Rodríguez-Mayorgas A. Romulus, Aeneas and the Cultural Memory of the Roman Republic. Athenaeum. 2010;98:89-110.

12. Blázquez JM. Mitos del mosaico de Cástulo. 7esquinas. 2014, 6: 109-16.

13. Neira ML. Written and visual culture about the Mosaic of Cástulo:the influence of Lucian's works. J Mosaic Res. 2015. https://doi.org/10.26658/ jmr.306315.

14. Neira ML, Fernández A. Arte romano de la Bética. 3, Mosaico, pintura, manufacturas. Sevilla: Focus-Abengoa; 2010.

15. Lledó JL. Mujeres, mitos y arquetipos femeninos en los mosaicos romanos en Noheda. In: Neira L, editor. Representaciones de mujeres en los mosaicos romanos y su impacto en el imaginario de estereotipos femeninos. Madrid: CVG; 2011. p. 225-38.

16. Neira ML. En torno al mosaico de los Amores de Cástulo. A propósito de la vinculación del profesor Blázquez con los mosaicos romanos y Cástulo. In: Camarero N, coordinator. Vir validus et nobilis. Homenaje a D. José María Blázquez Martínez. Linares: Centro de Estudios Linarenses; 2018. p. 239-266.

17. Navarro JV. Aplicaciones de la microscopía electrónica de barrido al estudio de los vidrios arqueológicos: las teselas vítreas de los mosaicos de la villa romana de Noheda (Cuenca). In: La Ciencia y el Arte III Ciencias experimentales y conservación del patrimonio. Madrid: Ministerio de Cultura; 2011. p. 105-120.

18. Schibille N, Boschetti C, Valero Tévar MA, Veron E, de Juan AJ. The Color Palette of the Mosaics in the Roman Villa of Noheda (Spain). Minerals. 2020. https://doi.org/10.3390/min10030272.

19. Colomban P, March G, Mazerolles L, Karmous T, Ayed N, Ennabli A, Slim $H$. Raman identification of materials used for jewellery and mosaics in Ifriqiya. J Raman Spectrosc. 2003. https://doi.org/10.1002/jrs.977.

20. Di Martino D, Galli A, Martini M. The intriguing case of silicon crystals unveiled in ancient mosaic tesserae. J Raman Spectrosc. 2012. https://doi. org/10.1002/jrs.4135.

21. Basso E, Invernizzi C, Malagodi M, La Russa MF, Bersani D, Lottici PP. Characterization of colorants and opacifiers in roman glass mosaic tesserae through spectroscopic and spectrometric techniques. J Raman Spectrosc. 2014. https://doi.org/10.1002/jrs.4449. 
22. Maltoni S, Silvestri A. Mosaic of Colors: investigating production technologies of Roman Glass Tesserae from Northeastern Italy. Minerals. 2018. https://doi.org/10.3390/min8060255.

23. Ion RM, Bakirov BA, Kichanov SE, Kozlenko DP, Belushkin AV, Radulescu C, Dulama ID, Bucurica IA, Gheboianu Al, Stirbescu RM, Teodorescu S, lancu L, David ME, Grigorescu RM. Non-Destructive and micro-invasive techniques for characterizing the ancient Roman Mosaic fragments. Appl Sci. 2020. https://doi.org/10.3390/app10113781.

24. Licenziati F, Calligaro T. Study of mosaic glass tesserae from Delos, Greece using a combination of portable $\mu$-Raman and X-ray fluorescence spectrometry. J Archaeol Sci Rep. 2016. https://doi.org/10.1016/j. jasrep.2015.10.017.

25. Donais MK, Van Pevenage J, Sparks A, Redente M, George DB, Moens L, Vincze L, Vandenabeele P. Characterization of Roman glass tesserae from the Coriglia excavation site (Italy) via energy-dispersive X-ray fluorescence spectrometry and Raman spectroscopy. Appl Phys A. 2016. https://doi.org/10.1007/s00339-016-0566-x.

26. Marcaida I, Maguregui M, Morillas $H$, Prieto-Taboada N, Veneranda M, Fdez-Ortiz de Vallejuelo S, Martellone A, De Nigris B, Osanna M, Madariaga JM. In situ non-invasive multianalytical methodology to characterize mosaic tesserae from the House of Gilded Cupids, Pompeii. Herit Sci. 2019. https://doi.org/10.1186/s40494-019-0246-1.

27. Rousaki A, Costa M, Saelens D, Lycke S, Sánchez A, Tuñón J, Ceprián B, Amate P, Montejo M, Mirao J, Vandenabeele P. A comparative mobile Raman Study for the on field analysis of the Mosaico de los Amores of the Cástulo Archaeological Site (Linares, Spain). J Raman Spectrosc. 2019. https://doi.org/10.1002/jrs.5624.

28. Costa M, Rousaki A, Lycke S, Saelens D, Tack P, Sánchez A, Tuñón J, Ceprián B, Amate P, Montejo M, Mirão J, Vandenabeele P. Comparison of the performance of two handheld XRF instruments in the study of Roman tesserae from Cástulo (Linares, Spain). Eur Phys J Plus. 2020. https://doi.org/10.1140/epjp/s13360-020-00635-x.

29. GigaPan. http://gigapan.com/gigapans?tags=Castulo. Accessed Oct 2020.

30. Tuñón JA, Sánchez A, Parras DJ, Vandenabeele P, Montejo M. MicroRaman Spectroscopy on Iberian archaeological materials. J Raman Spectrosc. 2016. https://doi.org/10.1002/jrs.4934.

31. Sánchez A, Tuñón JA, Parras DJ, Montejo M, Lechuga MA, Ceprián B, Soto M, Luque A. MRS, EDXRF and GC-MS analysis for research on the ritual and funerary areas of Cerro de los Vientos (Baeza, Jaén, Spain) Native and Eastern Mediterranean influences. J Archaeol Sci Rep. 2019. https://doi.org/10.1016/j.jasrep.2019.102026.

32. Burgio L, Clark RJ. Library of FT-Raman spectra of pigments, minerals, pigment media and varnishes, and supplement to existing library of Raman spectra of pigments with visible excitation. Spectrochim Acta A. 2001. https://doi.org/10.1016/S1386-1425(00)00495-9.

33. Bouchard M, Smith DC. Catalogue of 45 reference Raman spectra of minerals concerning research in art history or archaeology, especially on corroded metals and coloured glass. Spectrochim Acta A. 2003. https://doi.org/10.1016/S1386-1425(03)00069-6.

34. Colomban P, Tournié A, Bellot-Gurlet L. Raman identification of glassy silicates used in ceramics, glass and jewellery: a tentative differentiation guide. J Raman Spectrosc. 2006. https://doi.org/10.1002/jrs.1515.

35. RRUFF database. https://rruff.info/ Accessed Oct 2020.

36. Vekemans B, Janssens K, Vincze L, Adams F, Van Espen P. Analysis of $X$-ray spectra by iterative least squares (AXIL): New developments. X-Ray Spectrom. 1994. https://doi.org/10.1002/xrs.1300230609.

37. Vekemans B, Janssens K, Vincze L, Adams F, Van Espen P. Comparison of several background compensation methods useful for evaluation of energy-dispersive X-ray fluorescence spectra. Spectrochim Acta B. 1995. https://doi.org/10.1016/0584-8547(94)00118-F.

38. Forster N, Grave P. Effects of elevated levels of lead in ceramics on provenancing studies using non-destructive PXRF: a case study in Byzantine Cypriot glazed ceramics. X-Ray Spectrom. 2013. https://doi. org/10.1002/xrs.2507.

39. Calparsoro E, Maguregui M, Morillas H, Arana G, Iñañez JG. Nondestructive screening methodology based on ED-XRF for the classification of medieval and post-medieval archaeological ceramics. Ceram Int. 2019. https://doi.org/10.1016/j.ceramint.2019.02.138.
40. Adlington LW, Gratuze B, Schibille N. Comparison of pXRF and LA-ICP-MS analysis of lead-rich glass mosaic tesserae. J Archaeol Sci Rep. 2020. https ://doi.org/10.1016/j.jasrep.2020.102603.

41. Adlington L, Freestone IC. Using handheld pXRF to study medieval stained glass: a methodology using trace elements. MRS Adv. 2017. https ://doi.org/10.1557/adv.2017.233.

42. Marín P, Dorado A. Aportaciones al estudio de la cadena operativa del mosaico romano: análisis tecnológico de teselas cerámicas de la villa de los Vergeles (Granada). Antiquitas. 2014;26:227-34.

43. Pérez de Dios V, de Soto García MR, de Soto García I, García Giménez R. Archaeometric study of Roman tesserae from Salamanca (Spain). Archaeology and geochemical analysis. Interdiscip. Archaeol. 2018; https://doi. org/10.24916/iansa.2018.1.3.

44. Taylor R, Ontiveros-Ortega E, Beltrán-Fortes J. Estudio Arqueométrico del Mosaico del Nacimiento de Venus de Cartima (Cártama, Málaga). Macla. 2012;16:40-1.

45. Neri E, Morvan C, Colomban P, Guerra MF, Prigent V. Late Roman and Byzantine mosaic opaque "glass-ceramics" tesserae (5th-9th century). Ceram Int. 2016. https://doi.org/10.1016/j.ceramint.2016.09.033.

46. Robinet L, Coupry C, Eremin K, Hall C. The use of Raman spectrometry to predict the stability of historic glasses. J Raman Spectrosc. 2006. https:// doi.org/10.1002/jrs.1540.

47. Tournié A, Prinsloo LC, Colomban P. Raman classification of glass beads excavated on Mapungubwe hill and K2, two archaeological sites in South Africa. J Raman Spectrosc. 2012. https://doi.org/10.1002/jrs.3069.

48. Sun J, Wu Z, Cheng H, Zhang Z, Frost RL. A Raman spectroscopic comparison of calcite and dolomite. Spectrochim Acta A. 2014. https://doi. org/10.1016/j.saa.2013.08.014.

49. Germinario C, Francesco I, Mercurio M, Langella A, Sali D, Kakoulli I, De Bonis A, Grifa C. Multi-analytical and non-invasive characterization of the polychromy of wall paintings at the Domus of Octavius Quartio in Pompeii. Eur Phys J Plus. 2018. https://doi.org/10.1140/epjp/i2018-12224 $-6$.

50. De Faria DLA, Lopes FN. Heated goethite and natural hematite: can Raman spectroscopy be used to differentiate them? Vib Spectrosc. 2007. https://doi.org/10.1016/j.vibspec.2007.07.003.

51. Bandiera M, Lehuédé P, Verità M, Alves L, Biron I, Vilarigues M. Nanotechnology in Roman Opaque Red Glass from the 2nd Century AD. Archaeometric Investigation in red Sectilia from the Decoration of the Lucius Verus Villa in Rome. Heritage 2019; https://doi.org/10.3390/herit age2030159.

52. Henderson J. The science and archaeology of materials: an investigation of inorganic materials. London: Routledge; 2000.

53. Henderson J. Silica, lime and glass colourants. In: Henderson J, editor. Ancient Glass: An Interdisciplinary Exploration. Cambridge: Cambridge University Press; 2013. p. 56-82.

54. Gedzevičiūtè V, Welter N, Schüssler U, Weiss C. Chemical composition and colouring agents of Roman mosaic and millefiori glass, studied by electron microprobe analysis and Raman microspectroscopy. Archaeol Anthrop Sci. 2009. https://doi.org/10.1007/s12520-009-0005-4.

55. Merriman RJ, Highley DE, Cameron DG. Definition and characteristics of very-fine grained sedimentary rocks: clay, mudstone, shale and slate. British Geological Survey Commissioned Report: 20; 2003. http://nora.nerc. ac.uk/id/eprint/527458/. Accessed 15 Oct 2020.

56. Force ER. Geology of Titanium-Mineral Deposits. Especial paper 259 Boulder, Colorado: Geological Society of America; 1991.

57. García-Heras M, Rincón JM, Jimeno A, Martínez A, Villegas MA. Estudio arqueométrico de cuentas de vidrio procedentes de la necrópolis de Numancia (siglo II a.C.). Trabajos de Prehistoria 2003; http://hdl.handl e.net/10261/8815.

58. Smirniou M, Rehren Th. Shades of blue-cobalt-copper coloured blue glass from New Kingdom Egypt and the Mycenaean world: a matter of production or colourant source? J Archaeol Sci. 2013. https://doi. org/10.1016/j.jas.2013.06.029.

59. Oikonomou A, Henderson J, Gnade M, Chenery S, Zacharias N. An archaeometric study of Hellenistic glass vessels: evidence for multiple sources. Archaeol Anthropol Sci. 2018. https://doi.org/10.1007/s1252 0-016-0336-x.

60. Arletti R, Quartieri S, Vezzalini G. Glass mosaic tesserae from Pompeii: an archeometrical investigation. Per Mineral. 2006;76(2):25-38. 
61. Di Bella M, Quartieri S, Sabatino G, Santalucia F, Triscari M. The glass mosaics tesserae of "Villa del Casale" (Piazza Armerina, Italy): a multitechnique archaeometric study. Archaeol Anthropol Sci. 2013. https://doi. org/10.1007/s12520-013-0172-1.

62. Barca D, Basso E, Bersani D, Galli G, Invernizzi C, La Russa MF, Lottici PP, Malagodi M, Ruolo SA. Vitreous tesserae from the calidarium mosaics of the Villa dei Quintili, Rome. Chemical composition and production technology. Microchem J. 2016. https://doi.org/10.1016/j.microc.2015.10.037.

63. Vataj E, Hobdari E, Röhrs S, Vandenabele P, Civici N. Analytical characterization of glass tesserae from mosaics of early Christian basilicas in Albania. Appl Phys. 2017. https://doi.org/10.1007/s00339-016-0661-z.

64. Jackson CM, Cottam S. 'A green thought in a green shade'; Compositional and typological observations concerning the production of emerald green glass vessels in the 1st century A.D. J Archaeol Sci. 2015. https:// doi.org/10.1016/j.jas.2015.05.004.

65. Ricciardi P, Colomban P, Tournie A, Macchiarola M, Ayed N. A non-invasive study of Roman Age mosaic glass tesserae by means of Raman spectroscopy. J Archaeol Sci. 2009. https://doi.org/10.1016/j.jas.2009.07.008.

66. Lahlil S, Cotte M, Biron I, Szlachetko J, Menguye N, Susinib J. Synthesizing lead antimonate in ancient and modern opaque glass. J Anal At Spectrom. 2011. https://doi.org/10.1039/COJA00251H.

67. Barca D, Fiorenza E, D'Andrea M, Le Pera E, Musella M, Sudano F, Taliano Grasso A. Chemical and Petrographic Characterization of Stone and Glass Tesserae in the Nereid and Geometric Mosaics from the S Aloe Quarter in Vibo Valentia-Calabria, Italy. Minerals. 2019. https://doi.org/10.3390/ $\min 9120729$

68. Practical VP, Spectroscopy R. An introduction. Chichister: John Wiley \& Sons Ltd; 2013.

69. Rostron P, Gaber S, Gaber D. Raman spectroscopy. Review Int J Eng Tech Res. 2016;6:50-64

70. Caggiani MC, Colomban P, Valotteau C, Mangone A, Cambon P. Mobile Raman spectroscopy analysis of ancient enamelled glass masterpieces. Anal Methods. 2013;5:4345-54. https://doi.org/10.1039/C3AY40648B.

71. Liritzis I, Zacharias N. Portable XRF of archaeological artifacts: current research, potentials and limitations. In: Shackley MS, editor. X-Ray Fluorescence Spectrometry (XRF) in geoarchaeology. New York: Springer Science; 2011. p. 109-42.

72. Giakoumaki A, Maguregui M, Martínez-Arkarazo I, Knuutinen U, Castro K, Madariaga JM. Portable spectroscopic instrumentation at the service of archaeologists and conservators for non-invasive in situ analysis: the case of Pompeii. Coalition. 2012;23:6-12.

73. Šmuc A, Dolenec M, Lesar-Kikelj M, Lux J, Pflaum M, Šeme B, Županek B, Gale L, Kramar S. Variety of Black and White Limestone Tesserae Used in Ancient Mosaics in Slovenia. Archaeometry. 2017. https://doi. org/10.1111/arcm.12250.

74. Luna JV. Mosaicos teselados en el mundo romano La casa de Baco desde la mirada de un musivario. Revista electrónica ReCoPaR. 2013:10:1-43.

75. Martín LM, Parra, J, Matas J, Roldán, FJ, Martín, A. Martínez D, González, F. Mapa Geológico de España, Escala 1:200.000, Hoja 70 (Linares), 555 Instituto Geológico y Minero de España, 2009.

76. López MC, Mingarro F. Estudio petrográfico de los mosaicos. In: Fernández-Galiano D, editor. Complutum II. Mosaicos. Excavaciones
Arqueológicas en España. Madrid: Ministerio de Cultura; 1984. p. 227-234.

77. Arboledas L, Contreras F, Onorato A. La explotación masiva de los recursos mineros de sierra morena oriental: la minería iberorromana. CPAG. 2014;24:111-45.

78. Parras D, Vandenabeele P, Sánchez A, Montejo M, Moens L, Ramos N. Micro-Raman spectroscopy of decorated pottery from the Iberian archaeological site of Puente Tablas (Jaén, Spain, 7th-4th century BC). J Raman Spectrosc. 2010. https://doi.org/10.1002/jrs.2405.

79. Doehne E, Price C. Stone conservation: an overview of current research. Los Angeles: Getty Conservation Institute; 2010.

80. Navarro J. Diagnosis, alteraciones y evaluación de tratamientos en calizas y areniscas. Instituto del Patrimonio Cultural de España. 2013.

81. Barnoos $\mathrm{V}$, Oudbashi $\mathrm{O}$, Shekofteh $\mathrm{A}$. The deterioration process of limestone in the Anahita Temple of Kangavar (West Iran). Heritage Sci. 2020. https://doi.org/10.1186/s40494-020-00411-1.

82. Ontiveros-Ortega E, Beltrán-Fortes J, Loza ML, Taylor R. Análisis Arqueométrico del Mosaico Romano de la Villa de Puerta Oscura (Málaga). Macla. 2015;20:107-8.

83. Palomar T, Garcia-Heras M, Saiz-Jimenez C, Márquez C, Villegas MA. Pathologies and analytical study of mosaic materials from Carmona and Italica. Materiales de Construcción. 2011. https://doi.org/10.3989/ mc.2011.64310

84. Millán ML, Gómez MC. El mosaico de la villa romana de Puente Melchor Estudio histórico-artístico y tratamientos de conservación. ROMVLA. 2012; 11: 115-136.

85. Durante A, Domínguez S, Bernal D. The Mosaic of Baco (Puente Melchor, Cádiz), a new archaeometric approach. In: Mosquera MJ, Almoraima ML, editors. Conserving Cultural Heritage. London: CRC Press, Balkema; 2018. p. $281-284$

86. Flores V, Alejandre FJ, Martín del Río JJ, Enríquez C. Restauración de un mosaico romano: caracterización y análisis constructivo. Revista PH. 2004;12:94-101.

87. Márquez C. El mosaico de las estaciones de Carmona. Estudios previos conservación-restauración. ROMVLA 2016; 15: 227-254.

88. Degryse P, Scott RB, Brems D. The archaeometry of ancient glassmaking reconstructing ancient technology and the trade of raw materials. Perspective: la revue de I'INHA: actualités de la recherche en histoire de l'art. 2014; 2: 224-238.

89. Palomar T, García-Heras M, Villegas MA. Model historical glasses under simulated burial conditions. Coalition. 2012;23:1-6.

90. Pascual Sánchez MA, Bernal-Casasola D, Domínguez-Bella S, Durante Macías A, Expósito Álvarez JA, Díaz Rodríguez JJ, Millán Salgado ML. El mosaico de las Termas Marítimas de Baelo Claudia: contexto, iconografía, arqueometría y restauración. Anales de Arqueología Cordobesa 2019; https://doi.org/10.21071/aac.v30i.12440.

\section{Publisher's Note}

Springer Nature remains neutral with regard to jurisdictional claims in published maps and institutional affiliations.

\section{Submit your manuscript to a SpringerOpen ${ }^{\circ}$ journal and benefit from:}

- Convenient online submission

- Rigorous peer review

- Open access: articles freely available online

- High visibility within the field

Retaining the copyright to your article

Submit your next manuscript at springeropen.com 